\title{
Observations of $\mathrm{OM} / \mathrm{OC}$ and specific attenuation coefficients (SAC) in ambient fine PM at a rural site in central Ontario, Canada
}

\author{
T. W. Chan ${ }^{1, *}$, L. Huang ${ }^{1}$, W. R. Leaitch ${ }^{1}$, S. Sharma ${ }^{1}$, J. R. Brook ${ }^{1}$, J. G. Slowik ${ }^{2}$, J. P. D. Abbatt ${ }^{2}$, P. C. Brickell ${ }^{1}$, \\ J. Liggio ${ }^{1}$, S.-M. Li ${ }^{1}$, and H. Moosmüller ${ }^{3}$ \\ ${ }^{1}$ ASTD/STB, Environment Canada, 4905 Dufferin Street, Toronto, Ontario, M3H 5T4, Canada \\ ${ }^{2}$ Department of Chemistry, University of Toronto, Lash Miller Chemical Laboratories, 80 St. George Street, Toronto, Ontario, \\ M5S 3H6, Canada \\ ${ }^{3}$ Division of Atmospheric Sciences, Desert Research Institute, 2215 Raggio Parkway, Reno, Nevada, 89512-1095, USA \\ *now at: ASTD/STB, Environment Canada, 335 River Road, Ottawa, Ontario, K1A 0H3, Canada
}

Received: 5 May 2009 - Published in Atmos. Chem. Phys. Discuss.: 1 July 2009

Revised: 27 February 2010 - Accepted: 1 March 2010 - Published: 9 March 2010

\begin{abstract}
Ambient particulate matter (PM) samples were collected on quartz filters at a rural site in central Ontario during an intensive study in 2007. The concentrations of organic carbon (OC), pyrolysis organic carbon (POC), and elemental carbon (EC) were determined by thermal analysis. The concentrations are compared to the organic aerosol mass concentration (OM) measured with an Aerodyne C-ToF Aerosol Mass Spectrometer (AMS) and to the particle absorption coefficient $\left(b_{\text {asp }}\right)$ obtained from a Radiance Research Particle Soot Absorption Photometer (PSAP). The total organic mass to organic carbon ratios $(\mathrm{OM} / \mathrm{OC})$ and specific attenuation coefficients $\left(\mathrm{SAC}=b_{\mathrm{asp}} / \mathrm{EC}\right)$ are derived. Proportionality of the POC mass with the oxygen mass in the aerosols estimated from the AMS offers a potential means to estimate OM/OC from thermal measurements only. The mean SAC for the study is $3.8 \pm 0.3 \mathrm{~m}^{2} \mathrm{~g}^{-1}$. It is found that the SAC is independent of or decrease with increasing particle mass loading, depending on whether or not the data are separated between aerosols dominated by more recent anthropogenic input and aerosols dominated by longer residence time or biogenic components. There is no evidence to support an enhancement of light absorption by the condensation of secondary material to particles, suggesting that present model simulations built on such an assumption may overestimate atmospheric warming by $\mathrm{BC}$.
\end{abstract}

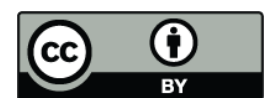

Correspondence to: L. Huang (lin.huang@ec.gc.ca)

\section{Introduction}

Carbonaceous species, consisting of organic carbon (OC) and elemental carbon (EC), make up a large fraction of the fine atmospheric particulate mass in urban, rural, marine, and forest environments (e.g., Hildemann et al., 1996; Novakov et al., 1997; Middlebrook et al., 1998; Alves et al., 2006; Zhang et al., 2007; Bahadur et al., 2009). These species influence air quality, human health, and climate change (e.g., Japar et al., 1986; Dockery et al., 1992; Novakov and Penner, 1993; Cheng and Tsai, 2000; Satheesh and Moorthy, 2005; Viana et al., 2008).

Fine particle OC comes from direct emissions (e.g., fossil fuel combustions, biomass burning) as well as from the formation of secondary organic aerosol (SOA). SOA can be formed from both anthropogenic and biogenic origins as VOCs come from many anthropogenic and biogenic sources (Seinfeld and Pandis, 1998; Hoffmann et al., 1998; Cabada et al., 2002; Alfarra et al., 2006; Robinson et al., 2007; Laaksonen et al., 2008; Kroll and Seinfeld, 2008). Important biogenic VOCs include isoprene, monoterpenes, and sesquiterpenes from vegetation (Pio et al., 2001; Kavouras et al., 1998; Fehsenfeld et al., 1992), while the major anthropogenic VOCs include various aromatics, alkanes, alkenes, and carbonyls from vehicle emissions (Volkamer et al., 2006; Fraser et al., 1998; Kawamura and Kaplan, 1987). VOCs are oxidized in the atmosphere primarily by hydroxyl radical $(\mathrm{OH})$, ozone $\left(\mathrm{O}_{3}\right)$, and the nitrate radical $\left(\mathrm{NO}_{3}\right)$. Thus, the amount of SOA formed is related to the amount of VOCs as well as the available amount of oxidants.

Published by Copernicus Publications on behalf of the European Geosciences Union. 
EC comes from direct emissions (i.e., primary sources) due to incomplete combustion at the source (Horvath, 1993). Major EC sources include biomass burning and fossil fuel combustions. In the past, the term "soot" has also been used to refer to a substance produced during incomplete combustions (which generally contains primarily EC and some OC). The ratio of OC to EC in ambient aerosols varies due to different emission sources and can be increased by secondary processes.

Various thermal and thermal/optical techniques have been used to analyse OC and EC from quartz filter measurements (e.g., Huntzicker et al., 1982; Cachier et al., 1989a, b; Turpin et al., 1990; Chow et al., 1993, 2001; Huang et al., 2006). Classifications of the OC and EC using the different techniques are subject to the corresponding operating conditions, and therefore, the OC/EC determination is operationally defined (Chow et al., 1993, 2001). The distinction between OC and EC is complicated by the formation of charred organic carbon during the thermal separation procedure. Pyrolysis organic carbon (POC), usually referred to as charred OC, is the thermo-decomposed organic matter formed in a pure helium environment. Charred OC has similar morphological features as the source $\mathrm{OC}$ and is thermally decomposed at lower temperatures than EC (Han et al., 2007). The amount of charred OC depends on many factors, such as the nature of $\mathrm{OC}$, the mass concentration of oxygenated compounds, heating temperature, heating periods, and the supply of oxygen (Gelencsér, 2004; Cachier et al., 1989a, b). In the past, charred OC is often treated as an analysis artifact during thermal analysis and not much attention was given to its potential usage in relating to aerosol composition. Laboratory studies suggest that the amount of POC, defined as the carbon obtained via a thermal method from $550^{\circ} \mathrm{C}$ to $870^{\circ} \mathrm{C}$ under pure helium, is related to the amount of oxygenated organic carbon in the particles (Huang et al., 2006). Thus, the quantity of the POC might be able to provide some insights into SOA formation via photochemical oxidations.

The relative level of oxidation of the organic material in the atmospheric aerosol (OM/OC) has been used as an estimate of the degree of chemical processing in the atmosphere (de Gouw et al., 2005; Aiken et al., 2008). The value of the $\mathrm{OM} / \mathrm{OC}$ for ambient aerosols is subject to many factors, including the methodology in estimation (Turpin and Lim, 2001). In the past, various methods were used to estimate OM/OC for atmospheric aerosols by different authors; these are summarized in Table 1. A factor of 1.4 was first determined by White and Roberts (1977) using the data from Grosjean and Friendlander (1975). Turpin and Lim (2001) re-calculated the OM/OC ratio for several published studies and suggested the use of values of 1.6 and 2.1 for OM/OC for urban and rural sites, respectively. Russell (2003) used Fourier Transform InfraRed (FTIR) spectroscopy to estimate OC for computing OM/OC and found that $90 \%$ of the results were within the range from 1.2 to 1.6 , with an average of 1.4. El-Zanan et al. (2006) estimated OM and OC in solvent extracts of the archived filters from IMPROVE (Interagency Monitoring of Protected Visual Environments) network for US national parks and found that $\mathrm{OM} / \mathrm{OC}$ ranged from 1.6 to 2.6. Applying the mass balance method to the same samples, El-Zanan et al. estimated the value of OM/OC to vary between 1.5 and 2.2. An average of 2.1 was found across IMROVE network. Bae et al. (2006) applied a reconstructed mass balance technique to 3-year measurements at two measurement sites and found that the value of $\mathrm{OM} / \mathrm{OC}$ ranged from 1.5 to 1.9 at the rural site and from 1.3 to 1.6 at the urban site, with the rural results exhibiting a discernable seasonal pattern. Zhang et al. (2005a) applied a de-convolution technique to AMS mass spectra measured in Pittsburgh (Zhang et al., 2005b) to extract the mass spectra for oxygenated organic aerosol (OOA) and hydrocarbon-like organic aerosol (HOA). Based on the $m / z$ ratios in the individual spectra, they estimated the mean OM/OC was 1.8. Aiken et al. (2008) used the sum of the $\mathrm{C}_{\mathrm{x}} \mathrm{H}_{\mathrm{y}} \mathrm{O}_{\mathrm{z}}$ and $\mathrm{C}_{\mathrm{x}}: \mathrm{H}_{\mathrm{y}}$ fragments measured with a High Resolution Time-of-Flight AMS sampling ambient particles in Mexico City and found the average OM/OC was 1.71 and the range over 6 days was 1.41 to 2.15 . These previous studies indicate that the $\mathrm{OM} / \mathrm{OC}$ ratio in ambient aerosols varies from 1.2 to 2.2 , due to influences from primary emissions and secondary formations. It is noted that the uncertainties of those methods might also cause some differences in the estimations. To our knowledge, there is not a method using thermal measurements only to estimate $\mathrm{OM} / \mathrm{OC}$ ratio (which will be explored in this study).

The specific attenuation coefficient (SAC) is the ratio of the light absorption coefficient $\left(b_{\text {asp }}\right)$ to the EC mass concentration. It is a measure of the relative effectiveness of light absorption by EC. The $b_{\text {asp }}$ is usually determined by Aethalometers or by Particle Soot Absorption Photometers (PSAP), whereas the EC is measured by a thermal or thermal/optical method (Jennings and Pinnick, 1980; Japar et al., 1986; Sharma et al., 2002). Estimates of the SAC, based on absorption measured with Aethalometers or Particle Soot Absorption Photometers (PSAP), vary from 2 to $55 \mathrm{~m}^{2} \mathrm{~g}^{-1}$ (Liousse et al., 1993; Snyder and Schauer, 2007). Variations in SAC are caused by differences in the particle composition, size, shape, structure and refractive index, including the possible presence of less absorbing components in the particles (Bond and Bergstrom, 2006; Bond et al., 2006; Liousse et al., 1993), and hence the SAC will differ from site to site (Liousse et al., 1993; Sharma et al., 2002). Experimental factors also influence the estimate of the SAC: the thickness of the filter used in an optical instrument to measure the light absorption (i.e., a thicker filter allows particles to become more deeply embedded in the filter matrix; Snyder and Schauer, 2007); the definition of EC in the thermal or thermal/optical method; filter-based light absorption measurements can have artifacts due the deposition of additional light scattering $\mathrm{OM}$ and inorganics onto the quartz fibers in the filter medium (Moosmüller et al., 2009; Subramanian et al., 2007). 
The effective value of the SAC in the atmosphere may increase through a lensing effect by non-absorbing OM or inorganics (e.g. sulphates, nitrates) condensing onto an EC core (e.g., Bond et al., 2006; Cappa et al., 2008; Lack et al., 2008), and it may decrease if the EC core collapses (Lewis et al., 2009; Liousse et al., 1993; Bond and Bergstrom, 2006; Fuller et al., 1999; Iskander et al., 1991). A better understanding of the influence from non-absorbing materials on light absorption helps to improve the prediction of aerosol light absorption by fine black carbon aerosols in the atmosphere, which eventually leads to better prediction of the global climate forcing.

Here we discuss measurements from an intensive campaign at a rural site about $75 \mathrm{~km}$ north of Toronto, Ontario. OC mass concentrations (determined by thermal analysis of quartz filters) are combined with measurements of OM mass concentrations (obtained from a C-ToF Aerodyne Aerosol Mass Spectrometer, i.e., C-ToF-AMS) to estimate OM/OC. The POC and EC were also determined from the thermal analysis of the quartz filters. The SAC is estimated from the particle light absorption coefficient $\left(b_{\text {asp }}\right)$ and the EC from the filters. Because the sampling location is influenced both by air masses from the south with higher aerosol loadings and cleaner air masses from the north, this provides the opportunity to study the variations of the OM/OC and SAC for aerosols with different sources and lifetimes. We examine the relationship between the measured POC mass and the level of oxygenation of the ambient aerosol as well as the variation of the SAC with increased fine particle mass loading.

\section{Sampling and measurements}

\subsection{Location of the study}

During the late spring of 2007, a one month intensive field study was conducted at the Centre for Atmospheric Research Experiments (CARE) of Environment Canada located near Egbert, Ontario ( $44^{\circ} 12^{\prime} \mathrm{N}, 79^{\circ} 48^{\prime} \mathrm{W}, 251 \mathrm{~m}$ a.s.l.), Canada. About $70 \mathrm{~km} \mathrm{NNW}$ of the city of Toronto, CARE is surrounded by crop land with no major local anthropogenic sources. Air that reaches the site from regions to the south contains anthropogenic pollutants originating within two days of urban and industrial areas of southern Ontario and the northeastern United States (Rupakheti et al., 2005; Chan and Mozurkewich, 2007). By comparison, air from the north is on average relatively clean; although when the air passes over Sudbury, Ontario, about $310 \mathrm{~km}$ NNW of CARE the sulphate measured at CARE often increases due to the $\mathrm{SO}_{2}$ emission from the metal refineries near Sudbury. During this study, there were periods when SOA formation from terpenes emitted from forests north of the site contributed significantly to the aerosol mass (Slowik et al., 2009). While such biogenic aerosols may also contribute to SOA in the southern air masses, such contributions are difficult to distinguish from the relatively large anthropogenic sources and the subsequent SOA formation.

\subsection{Sample collections and measurement methods}

\subsubsection{Integrated quartz filter measurements}

Daily samples of particles were collected on $47-\mathrm{mm}$ prefired quartz filters during from 15 May to 15 June 2007 for OC/EC analysis. Ambient air was sampled through a $1.9 \mathrm{~cm}$ inner diameter stainless steel tube with an inverted U-shaped inlet located about $10 \mathrm{~m}$ above ground. A $1.0 \mu \mathrm{m}$ cyclone was installed at the intake and surrounded with a metal shield to prevent rain drops or snow from entering it. The samples were collected at a flow rate of $31.0 \mathrm{~L} \mathrm{~min}^{-1}$. Blank filters were taken at different times during the course of the study. All filters were stored in freezers $\left(<-20^{\circ} \mathrm{C}\right)$ and analyzed after the field study. The OC, POC, and EC were measured by a thermal method instead of a ther$\mathrm{mal} /$ optical method although a thermal-optical transmittance (TOT) OC/EC analyzer was used (manufactured by Sunset Lab: www.sunlab.com). This thermal separation method (also called "EnCan_Total-900" method) was originally developed for OC/EC isotope measurements. In the method, no laser beam was used for OC/EC separation and much longer retention times were used for each individual carbon fractions to ensure good baseline separation (Huang, et al., 2006).

During each analysis run (using EnCan_Total-900 method), a $1.5 \mathrm{~cm}^{2}$ punch of the quartz filter is placed on a quartz boat that sits inside the TOT analyzer. Then, stepwise heating (from room temperature to $900^{\circ} \mathrm{C}$ ) is applied to the filter to separate different carbon fractions. Most of the low molecular weight non-refractory organic carbon (OC) masses are released at temperatures up to $550{ }^{\circ} \mathrm{C}$ under an oxygen-free and VOC-free He flow. In the second stage, the temperature is increased to $870{ }^{\circ} \mathrm{C}$ to release carbonate carbon (CC) and the pyrolysis organic carbon (POC). The term $\mathrm{POC}$ is used here to refer to the carbon mass released from $550^{\circ} \mathrm{C}$ to $870^{\circ} \mathrm{C}$ under pure helium environment, excluding carbonate carbon. The POC includes the charred OC formed during the first thermal stage $\left(550^{\circ} \mathrm{C}\right)$ and the refractory OC (including both oxygenated and nonoxygenated) that possess relatively high bonding energy and could not be released completely at temperatures up to $550{ }^{\circ} \mathrm{C}$. As shown from laboratory studies (Huang et al., 2006), the POC mass is generally related to the amount of oxygenated OC with no POC identified in the pure n-alkanes and PAHs mixtures. Isotope measurements are required to distinguish between CC from POC during the second stage. Previous isotopic measurements from filter samples collected at Egbert showed that insignificant amount of $\mathrm{CC}$ was found, indicating minimum impacts from soil dust and sea-salt aerosols (main sources of CC), and the carbon 
Table 1. A list of the OM/OC ratio obtained from various authors by different methodologies.

\begin{tabular}{cl}
\hline OM/OC ratio & Source \\
\hline 1.4 & White and Roberts (1977) \\
1.6 (urban) & Turpin and Lim (2001) \\
2.1 (rural) & Turpin and Lim (2001) \\
1.5 (forest) & Pio et al. (2001) \\
$1.2-1.6$ & Russell (2003) \\
$1.6-2.6$ & El-Zanan et al. (2006) \\
$1.3-1.6$ (urban) & Bae et al. (2006) \\
$1.5-1.9$ (rural) & Bae et al. (2006) \\
1.8 & Zhang et al. (2005b) \\
$1.4-2.2$ & Aiken et al. (2008) \\
\hline
\end{tabular}

fraction released during the second stage $\left(550-870^{\circ} \mathrm{C}\right)$ was dominated by POC (Huang et al., unpublished isotope data); negligible amount of $\mathrm{CC}$ is to be assumed for the measurements of all samples from the 2007 field study. At the final stage (i.e., the third stage), all the elemental carbon is released at $900^{\circ} \mathrm{C}$ with the supply of oxygen $\left(10 \% \mathrm{O}_{2}\right.$ with $90 \% \mathrm{He})$. In this thermal method, EC is separated from $\mathrm{POC}$ due to the greater resistance of the former to thermal pyrolysis, relative to the latter. The released $\mathrm{CO}_{2}$ from each stage is reduced to $\mathrm{CH}_{4}$ inside the methanator in the presence of $\mathrm{Ni}$ and $\mathrm{H}_{2}$, and finally measured by a flame ionization detector (FID). The retention time used in each step can be found in Huang et al. (2006). The accuracy, precision, and linearity range of this method using the TOT analyzer are $0.2,0.1$, and $1-17 \mu \mathrm{g} \mathrm{cm}^{-2}$, respectively (Huang et al., 2006). The majority of the measurements $(>90 \%)$ in this study were conducted within the linearity range of the analyzer. A constant OC blank correction, obtained as the average value of all blank filters taken during the field campaign, was applied to all sample filters in the study. The OC values for all samples after the blank correction are more than twice of the standard deviation of all the blank filters.

\subsubsection{Continuous measurements}

An Aerodyne C-ToF-AMS was used to make 5-min averaged mass concentration measurements of $\mathrm{OM}$, sulphate $\left(p \mathrm{SO}_{4}^{2-}\right)$, and nitrate $\left(p \mathrm{NO}_{3}^{-}\right)$in submicron particles. A short description follows; details on the design and operation of the AMS are available elsewhere (e.g., Jayne et al., 2000; Jimenez et al., 2003; Allan et al., 2003; Drewnick et al., 2005). Inside the AMS, aerosol particles are focused into a narrow beam in an aerodynamic lens and accelerated to a velocity dependent on their vacuum aerodynamic diameter. The particles impact on a resistively heated surface $\left(\sim 600^{\circ} \mathrm{C}\right)$, and the volatile and semi-volatile components of the particles vaporize. The vapour is ionized by electron impact and the positive ions are analyzed using time of flight mass spectrometry. The AMS was operated in the common mode of switching between measurements of total mass concentrations and size-dependent mass concentrations. The AMS transmission efficiency (TE) is close to $100 \%$ for particles from about 100-700 $\mathrm{nm}$ vacuum aerodynamic diameter (Liu et al., 2007). We include here measurements from a High Resolution Time of Flight Aerosol Mass Spectrometer (HR-ToF-AMS) that was operated beside the C-ToF-AMS to provide a direct estimate of the $\mathrm{O}$ mass concentration in the particles. Otherwise, the mass concentrations reported here (e.g., OM, $p \mathrm{SO}_{4}^{2-}, p \mathrm{NO}_{3}^{-}$) are from the C-ToF-AMS. The HR-ToF-AMS is similar to the C-ToF-AMS with the notable exception that the ions produced in the HR-ToF-AMS travel further thus allowing substantially increased mass resolution. The intake point for the sampling by the AMSs was located about $6 \mathrm{~m}$ above ground, and the ambient aerosol particles were continuously pulled down in a $1.9 \mathrm{~cm}$ OD stainless steel tube at a flow rate of approximately $25 \mathrm{~L} \mathrm{~min}^{-1}$.

Depending on their composition and morphology, some of the particles that impact the oven inside the AMS may bounce, resulting in a lower particle collection efficiency (CE). The AMS CE is reduced mostly in situations for which ammonium sulphate represents a larger fraction $(>50 \%)$ of the fine particle aerosol (Mattew et al., 2008). For this study, the CE of the C-ToF-AMS was estimated from a comparison of the AMS and Scanning Mobility Particle Sizer (SMPS) measurements as well as a comparison of larger particle events measured using the AMS light scattering module with events detected by the mass spectrometer (Slowik et al., 2009). For the HR-ToF-AMS, the CE was estimated from a comparison of the AMS and SMPS measurements. Over the study, the C-ToF-AMS CE varied from 0.5 to 0.8 with an overall average value of 0.6 , and a similar CE was obtained for the HR-ToF-AMS. The C-ToF-AMS CE was averaged to the same filter sampling period and then applied individually to the different C-ToF-AMS quantities. After that, the CE corrected C-ToF-AMS quantities were used to compare with the filter samples. These comparisons will be deficient if there is significant mass between the upper TE of the AMS $(0.7 \mu \mathrm{m}$ VAD) and the $1 \mu \mathrm{m}$ cut of the cyclone.

A Radiance Research Particle Soot Absorption Photometer (PSAP) was used to measure the light absorption coefficient of the ambient particles. The PSAP provides a measurement of particle absorption by monitoring the change in the amount of light transmitted through a quartz filter as the particles are being deposited onto the filter. The light absorption coefficient of the sampled particles is estimated from the ratio of the rate of decreasing transmission (compared to that through a blank filter at the wavelength of $567 \mathrm{~nm}$ ) to the sample flow rate, using Beer Lambert law. The original PSAP data for both studies are in 1-min resolution. After removing occasional outliers and data periods during which the transmittance falls below $50 \%$, the in-situ data were converted to hourly averages, and then integrated to the same sampling interval as the filter measurements. All 
Table 2. Wind occurrence for filter measurements.

The breakdown of the wind occurrence in percentage for all filter samples. The first section of the table shows the results when all wind direction data are used whereas the second section represents results excluding data with low wind speed. The predominant wind direction is defined based on the criteria outlined in Sect. 3.1.

\begin{tabular}{|c|c|c|c|c|c|}
\hline \multirow{2}{*}{$\begin{array}{l}\text { Filter start } \\
\text { date }\end{array}$} & \multicolumn{2}{|c|}{ Include all data } & \multicolumn{2}{|c|}{ Exclude data $<2 \mathrm{~m} \mathrm{~s}^{-1}$} & \multirow{2}{*}{$\begin{array}{l}\text { Predominant wind } \\
\text { direction }\end{array}$} \\
\hline & $\begin{array}{c}\text { South } \\
\left(120^{\circ}-240^{\circ}\right)\end{array}$ & $\begin{array}{c}\text { North } \\
\left(300^{\circ}-60^{\circ}\right)\end{array}$ & $\begin{array}{c}\text { South } \\
\left(120^{\circ}-240^{\circ}\right)\end{array}$ & $\begin{array}{c}\text { North } \\
\left(300^{\circ}-60^{\circ}\right)\end{array}$ & \\
\hline 15 May 2007 & 5 & 86 & 0 & 88 & North \\
\hline 16 May 2007 & 0 & 54 & 0 & 35 & Others \\
\hline 17 May 2007 & 57 & 39 & 33 & 67 & Mixed \\
\hline 18 May 2007 & 43 & 36 & 0 & 100 & North \\
\hline 19 May 2007 & 0 & 91 & 0 & 100 & North \\
\hline 21 May 2007 & 47 & 35 & 25 & 75 & Mixed \\
\hline 22 May 2007 & 100 & 0 & 100 & 0 & South \\
\hline 23 May 2007 & 100 & 0 & 100 & 0 & South \\
\hline 24 May 2007 & 65 & 0 & 65 & 0 & South \\
\hline 25 May 2007 & 42 & 50 & 45 & 50 & Mixed \\
\hline 27 May 2007 & 37 & 16 & 40 & 13 & Mixed \\
\hline 28 May 2007 & 35 & 48 & 10 & 80 & North \\
\hline 29 Мay 2007 & 100 & 0 & 100 & 0 & South \\
\hline 30 May 2007 & 50 & 27 & 50 & 0 & South \\
\hline 31 May 2007 & 64 & 14 & 100 & 0 & South \\
\hline 1 Jun 2007 & 58 & 21 & 25 & 0 & Others \\
\hline 2 Jun 2007 & 83 & 2 & 83 & 0 & South \\
\hline 4 Jun 2007 & 70 & 26 & 40 & 60 & Mixed \\
\hline 5 Jun 2007 & 30 & 57 & 8 & 92 & North \\
\hline 6 Jun 2007 & 48 & 17 & 40 & 10 & Mixed \\
\hline 7 Jun 2007 & 100 & 0 & 100 & 0 & South \\
\hline 8 Jun 2007 & 26 & 65 & 31 & 63 & Mixed \\
\hline 9 Jun 2007 & 27 & 60 & 0 & 100 & North \\
\hline 10 Jun 2007 & 0 & 94 & 0 & 100 & North \\
\hline 11 Jun 2007 & 0 & 100 & 0 & 100 & North \\
\hline 12 Jun 2007 & 0 & 100 & 0 & 100 & North \\
\hline 13 Jun 2007 & 52 & 13 & 0 & 17 & Others \\
\hline 14 Jun 2007 & 91 & 9 & 100 & 0 & South \\
\hline
\end{tabular}

the absorption coefficient measurements are corrected for filter sampling size and flows. Details of the operation and calibration of a PSAP can be found elsewhere (e.g., Bond et al., 1999; Sharma et al., 2002).

\section{Results and discussion}

\subsection{Characterization of carbonaceous species}

Figure 1 shows the variations of $\mathrm{OC}, \mathrm{OC}_{\text {tot }}$ (i.e., $\mathrm{OC}+\mathrm{POC}$ ), $\mathrm{EC}$, the ratios of total organic carbon to elemental carbon $\left(\mathrm{OC}_{\mathrm{tot}} / \mathrm{EC}\right)$ and total organic carbon to total carbon $\left(\mathrm{OC}_{\mathrm{tot}} / \mathrm{TC}\right)$ for 2007 spring study. Measurements of OM, sulphate, and $b_{\text {asp }}$, obtained by averaging the in-situ measurements to the same sampling interval as the filter samples, are also included. With the notable exception of the
9-14 June biogenic period (Slowik et al., 2009), the OM, $b_{\text {asp }}$, and sulphate vary correspondingly across the sampling period, due to co-varying anthropogenic sources. The values of $\mathrm{OC}_{\mathrm{tot}} / \mathrm{EC}$ are opposite to the corresponding $\mathrm{OM}$, sulphate and $b_{\text {asp }}$ values.

In order to separate different source influences, we focus on measurements taken within two wind sectors: northerly $\left(300^{\circ}\right.$ to $60^{\circ}$; relatively clean air with some significant biogenic influence) and southerly $\left(120^{\circ}\right.$ to $240^{\circ}$; with a strong anthropogenic influence). In most cases, back trajectories (not shown here) are consistent with the local wind directions; hourly local wind directions are used to determine the predominant wind direction for each filter sample. Periods with mean wind speeds $<2 \mathrm{~m} \mathrm{~s}^{-1}$ were excluded from the analysis to avoid isotropic wind behavior (Kim and Hopke, 2004). Generally, the predominant wind direction for all 


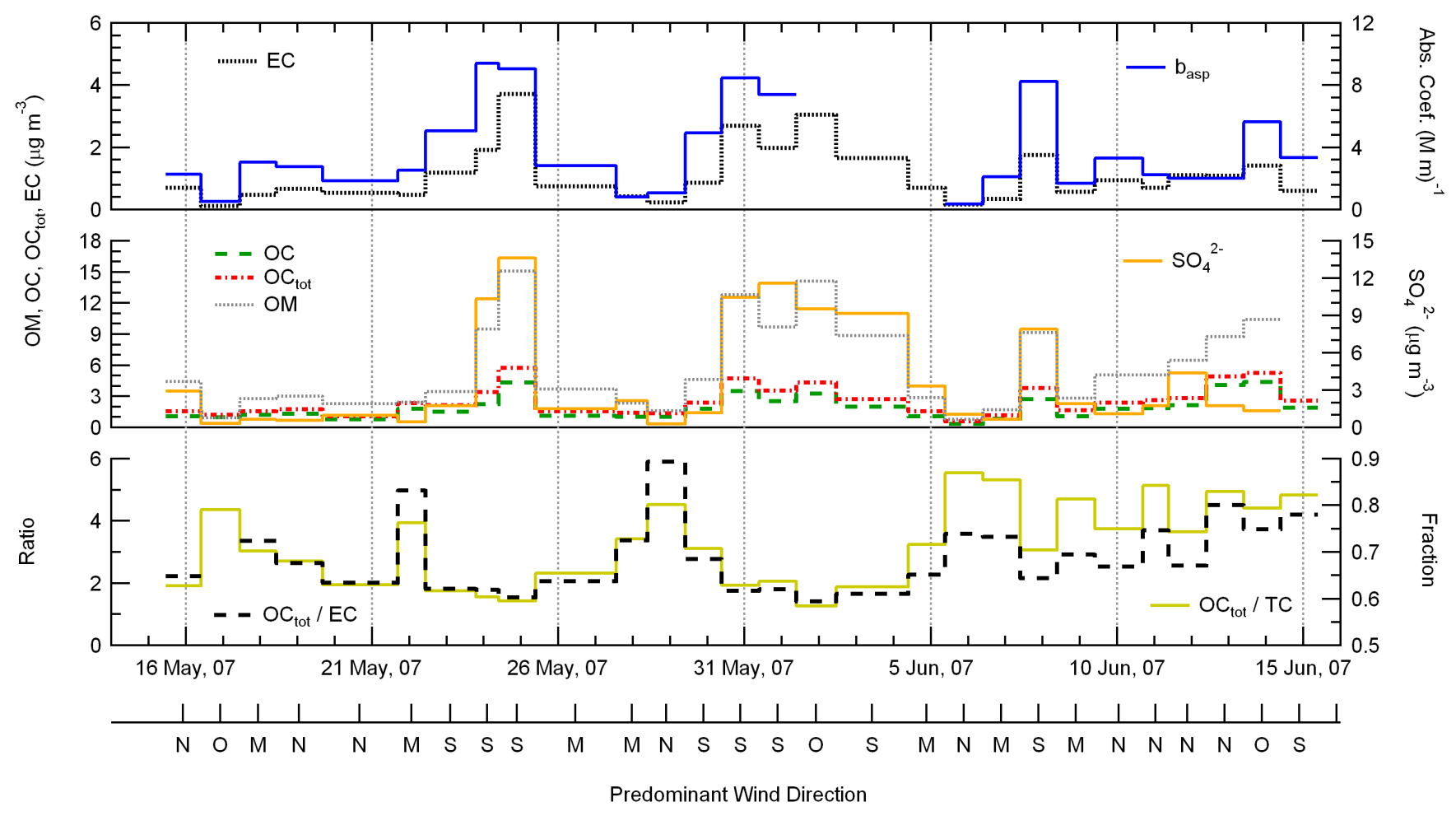

Fig. 1. Variations of organic carbon $(\mathrm{OC})$, total organic carbon $\left(\mathrm{OC}_{\mathrm{tot}}\right.$, i.e., $\left.\mathrm{OC}+\mathrm{POC}\right)$, elemental carbon (EC), total organic matter $(\mathrm{OM})$, sulphate, aerosol light absorption coefficient $\left(b_{\mathrm{asp}}\right)$, and the ratios of $\mathrm{OC}_{\mathrm{tot}} / \mathrm{EC}$ and $\mathrm{OC}_{\mathrm{tot}} / \mathrm{TC}$ during the 2007 spring study. Also given on the graph is the predominant wind direction for each corresponding filter sampling period ( $\mathrm{N}=$ north, $\mathrm{S}=$ south, $\mathrm{M}=\mathrm{mixed}, \mathrm{O}=\mathrm{others}$ ).

filter sampling periods is determined unambiguously (Table 2). The predominant wind direction within the sampling period of each filter measurement is based on two criteria: 1) the wind direction has to be within the given sampling interval at least $50 \%$ of the time; 2) the second predominant wind direction can not be within the sampling period more than $10 \%$ of the time. Based on these two criteria, the predominant wind direction is categorized as "north" $(\mathrm{N})$, "south" (S), "mixed" (M: only criterion 1 is fulfilled), and "others" $(\mathrm{O}$, where the predominant wind direction is from east or west and/or when criterion 1 is not fulfilled).

The values of $\mathrm{EC}, b_{\text {asp }}, \mathrm{OM}$ and $\mathrm{SO}_{4}^{2-}$ are generally higher in the southern air masses, whereas the $\mathrm{OC}_{\text {tot }} / \mathrm{EC}$ and $\mathrm{OC}_{\mathrm{tot}} / \mathrm{TC}$ ratios are generally higher in the northern air masses (Fig. 1). The higher EC concentrations and lower $\mathrm{OC}_{\text {tot }} / \mathrm{EC}$ in southern air reflect dominant contributions from primary anthropogenic sources (e.g., diesel emissions) while the relatively high $\mathrm{SO}_{4}^{2-}$ values imply influences from secondary formation via $\mathrm{SO}_{2}$ photo-oxidations. The relatively high $\mathrm{OM}$ values, correlated with $\mathrm{EC}$ and $\mathrm{SO}_{4}^{2-}$ suggest the contributions from both primary emissions and SOA.

9-14 June is an exceptional period that is identified as the "biogenic period" based on the analysis of Slowik et al. (2009). During the period, the winds were predominantly from the north and the sulphate mass was $<20 \%$ of the or- ganic mass, there was a steady increase in the organic mass concentration over a period of 5 days as the temperatures to the north at Egbert steadily increased, monoterpenes (as measured with a Proton-Transfer Mass Spectometer) increased, and the mixing ratios of acetylene (an anthropogenic tracer) were relatively low. This is in contrast to the air masses from the south for which acetylene VOCs and $\mathrm{NO}_{\mathrm{x}}$ increased significantly and sulphate was a dominant component of the fine particles. There are also a few other days with similar relative increases in $\mathrm{OM}$ in northerly air including 17,22 , and 30 May.

Table 3 shows the average concentrations for selected species and the ambient temperatures during the field studies based on the predominant wind direction. The results for the northern air masses are separated into three categories: 1) using all northern measurements (all), 2) including only the biogenic period from 9-14 June (bio), and 3) excluding the biogenic period (bg). During the biogenic period, the average value of the $\mathrm{OC}_{\mathrm{tot}} / \mathrm{TC}$ is $76 \pm 3 \%$, close to the average value of $74 \pm 3 \%$ for the northern air masses during other periods; these ratios are slightly higher than the $66 \pm 2 \%$ of the $\mathrm{OC}_{\mathrm{tot}} / \mathrm{TC}$ from the southern air masses due to the larger contributions from EC.

Also included in Table 3 are the average values of $\mathrm{OC}_{\mathrm{tot}} / \mathrm{EC}$ and $\mathrm{OC}_{\mathrm{tot}} / \mathrm{TC}$ (means of the ratios; 
Table 3. Average values for different species, the average total organic carbon to elemental carbon ratio $(\mathrm{OC}$ tot $/ E C ; O C$ tot $=O C+P O C)$, and the average total organic carbon to total carbon ratio $\left(\mathrm{OC}_{\mathrm{tot}} / \mathrm{TC}\right)$ measured during the 2007 study for different predominant wind directions. Results for the northern air masses are calculated using all northern data (all), excluding the biogenic period from June 9-14 (bg), and only the biogenic period (bio). The value given in the parenthesis is standard deviation of the mean (i.e., standard error). Also included are the average temperatures during different periods. Organic carbon (OC), pyrolysis organic carbon (POC), and elemental carbon (EC) data are obtained from filter measurements, $b_{\text {asp }}$ data are obtained from PSAP, OM data are from C-ToF-AMS.

\begin{tabular}{|c|c|c|c|c|}
\hline & 2007 N (all) & 2007 N (bg) & 2007 N (bio) & $2007 \mathrm{~S}$ \\
\hline $\mathrm{OC}, \mu \mathrm{g} \mathrm{m}^{-3}$ & $1.6( \pm 0.4)$ & $0.9( \pm 0.2)$ & $2.5( \pm 0.5)$ & $2.5( \pm 0.3)$ \\
\hline POC, $\mu \mathrm{g} \mathrm{m}^{-3}$ & $0.5( \pm 0.1)$ & $0.4( \pm 0.0)$ & $0.7( \pm 0.1)$ & $0.9( \pm 0.1)$ \\
\hline $\mathrm{EC}, \mu \mathrm{g} \mathrm{m}^{-3}$ & $0.7( \pm 0.1)$ & $0.5( \pm 0.1)$ & $1.0( \pm 0.1)$ & $1.8( \pm 0.3)$ \\
\hline $\mathrm{OM}, \mu \mathrm{g} \mathrm{m}^{-3}$ & $4.2( \pm 0.8)$ & $2.4( \pm 0.6)$ & $6.3( \pm 0.9)$ & $9( \pm 1)$ \\
\hline$b_{\mathrm{asp}},(\mathrm{Mm})^{-1}$ & $2.0( \pm 0.3)$ & $1.7( \pm 0.4)$ & $2.4( \pm 0.3)$ & $7.0( \pm 0.8)$ \\
\hline $\mathrm{OC}_{\mathrm{tot}} / \mathrm{EC}$ & $3.3( \pm 0.4)$ & $3.3( \pm 0.7)$ & $3.3( \pm 0.5)$ & $2.2( \pm 0.3)$ \\
\hline $\mathrm{OC}_{\text {tot }} / \mathrm{TC}$ & $0.75( \pm 0.02)$ & $0.74( \pm 0.03)$ & $0.76( \pm 0.03)$ & $0.66( \pm 0.02)$ \\
\hline Temp $\left({ }^{\circ} \mathrm{C}\right)$ & $14( \pm 2)$ & $11( \pm 2)$ & $18( \pm 1)$ & $21( \pm 1)$ \\
\hline
\end{tabular}

$\left.\mathrm{OC}_{\mathrm{tot}}=\mathrm{OC}+\mathrm{POC}\right)$. Observations from other studies show that the value of OC/EC derived either from the use of emissions inventory data or ambient measurements with limited SOA formation varies from 0.9 to 3.1 (e.g., Gray, 1986; Turpin and Huntzicker, 1991, 1995; Strader et al., 1999; Cabada et al., 2004). With larger contributions of SOA, the value of OC/EC can be much higher (e.g., 4.1-7.3 in Turpin and Huntzicker, 1991). At Egbert, the average value of $\mathrm{OC}_{\mathrm{tot}} / \mathrm{EC}$ is $2.2 \pm 0.3$ for the southern air masses and $3.3 \pm 0.4$ for the northern air masses. The larger $\mathrm{OC}_{\mathrm{tot}} / \mathrm{EC}$ values for the northern air masses suggest that SOA makes a relatively larger contribution to the total organic carbon than these from the southern air masses. This does not imply that all organics in the southern air masses reaching Egbert are from primary emissions. During the 2007 spring study, there is evidence for significant SOA formation in the southern air masses (Sect. 3.2.1).

The coefficients of determination $\left(R^{2}\right)$ between various quantities when the air masses were from the south and from the north are given in Table $4 \mathrm{a}$ and $4 \mathrm{~b}$, respectively. For the southern air masses $(N=8)$, the $R^{2}$ values between EC and POC, OC, OM are all 0.8-0.9, indicating that those components likely originated from common sources. The corresponding $R^{2}$ values are $0.4-0.8$ for aerosols from the north (Table $4 \mathrm{~b}$ ) and $0.0-0.5$ during the biogenic period. The lower $R^{2}$ for EC with POC, OC, and OM and the higher values of $\mathrm{OC}_{\mathrm{tot}} / \mathrm{EC}$ in the northern aerosol (Table 3) suggest a higher contribution from SOA. Regional model simulations suggest that the increase in SOA concentration for the northern biogenic period was primarily due to oxidation of monoterpenes (Slowik et al., 2009).
Table 4a. The coefficients of determination $\left(R^{2}\right)$ between different species measured during the 2007 spring study under heavy influence by southern air masses $(N=8)$.

\begin{tabular}{ccccccc}
\hline 2007 South & OC & POC & $\mathrm{EC}$ & $\mathrm{OM}$ & $\mathrm{SO}_{4}^{2-}$ & $b_{\text {asp }}$ \\
\hline $\mathrm{OC}$ & 1 & 0.8 & 0.9 & 0.9 & 0.6 & 0.5 \\
$\mathrm{POC}$ & 0.8 & 1 & 0.8 & 0.9 & 0.8 & 0.8 \\
$\mathrm{EC}$ & 0.9 & 0.8 & 1 & 0.9 & 0.7 & 0.7 \\
$\mathrm{OM}$ & 0.9 & 0.9 & 0.9 & 1 & 0.9 & 0.7 \\
$\mathrm{SO}_{4}^{2-}$ & 0.6 & 0.8 & 0.7 & 0.9 & 1 & 0.8 \\
$b_{\text {asp }}$ & 0.5 & 0.8 & 0.7 & 0.7 & 0.8 & 1 \\
\hline
\end{tabular}

\subsection{OM/OC ratio and POC}

\subsubsection{OM/OC and SOA formation}

Atmospheric oxidation of organic compounds generally leads to an increase in the oxygen content in the oxidized products and thus increases the ratio of OM to OC. Continued partitioning of the oxidized products onto aerosol particles over time increases the OM/OC ratio of the aerosol particles. One method for estimating the extent of atmospheric oxidation of an urban air mass is using the toluene to benzene ratio. Toluene and benzene are aromatic hydrocarbons mainly emitted from anthropogenic sources. Reactions of both toluene and benzene with $\mathrm{O}_{3}$ and with radical $\mathrm{NO}_{3}$ are relatively slow, and the most significant atmospheric removal process is by the reaction with $\mathrm{OH}$ radicals. Exposed to the same $\mathrm{OH}$ levels, toluene reacts about five times faster than benzene (Atkinson, 1990). For reasonable daily averaged $\mathrm{OH}$ concentrations of $10^{6}$ radicals $\mathrm{cm}^{-3}$, the atmospheric lifetimes for toluene and benzene are about 1.9 and 9.4 days, respectively. Due to their different photochemical 
Table 4b. The coefficients of determination $\left(R^{2}\right)$ between different species measured during the 2007 spring study under heavy influence by northern air masses. Values given in the table represent $R^{2}(\mathrm{~N}=5)$ excluding the biogenic period (9-14 June). Values in the parenthesis represent $R^{2}(N=4)$ during the biogenic period.

\begin{tabular}{ccccccc}
\hline 2007 North & OC & POC & $\mathrm{EC}$ & $\mathrm{OM}$ & $\mathrm{SO}_{4}^{2-}$ & $b_{\text {asp }}$ \\
\hline $\mathrm{OC}$ & 1 & $0.5(0.6)$ & $0.4(0.3)$ & $0.5(0.9)$ & $0.0(0.0)$ & $0.7(0.3)$ \\
$\mathrm{POC}$ & $0.5(0.6)$ & 1 & $0.7(0.0)$ & $0.9(0.6)$ & $0.4(0.0)$ & $0.7(0.7)$ \\
$\mathrm{EC}$ & $0.4(0.3)$ & $0.7(0.0)$ & 1 & $0.8(0.5)$ & $0.3(0.2)$ & $0.9(0.1)$ \\
$\mathrm{OM}$ & $0.5(0.9)$ & $0.9(0.6)$ & $0.8(0.5)$ & 1 & $0.5(0.0)$ & $0.7(0.4)$ \\
$\mathrm{SO}_{4}^{2-}$ & $0.0(0.0)$ & $0.4(0.0)$ & $0.3(0.2)$ & $0.5(0.0)$ & 1 & $0.1(0.4)$ \\
$b_{\text {asp }}$ & $0.7(0.3)$ & $0.7(0.7)$ & $0.9(0.1)$ & $0.7(0.4)$ & $0.1(0.4)$ & 1 \\
\hline
\end{tabular}

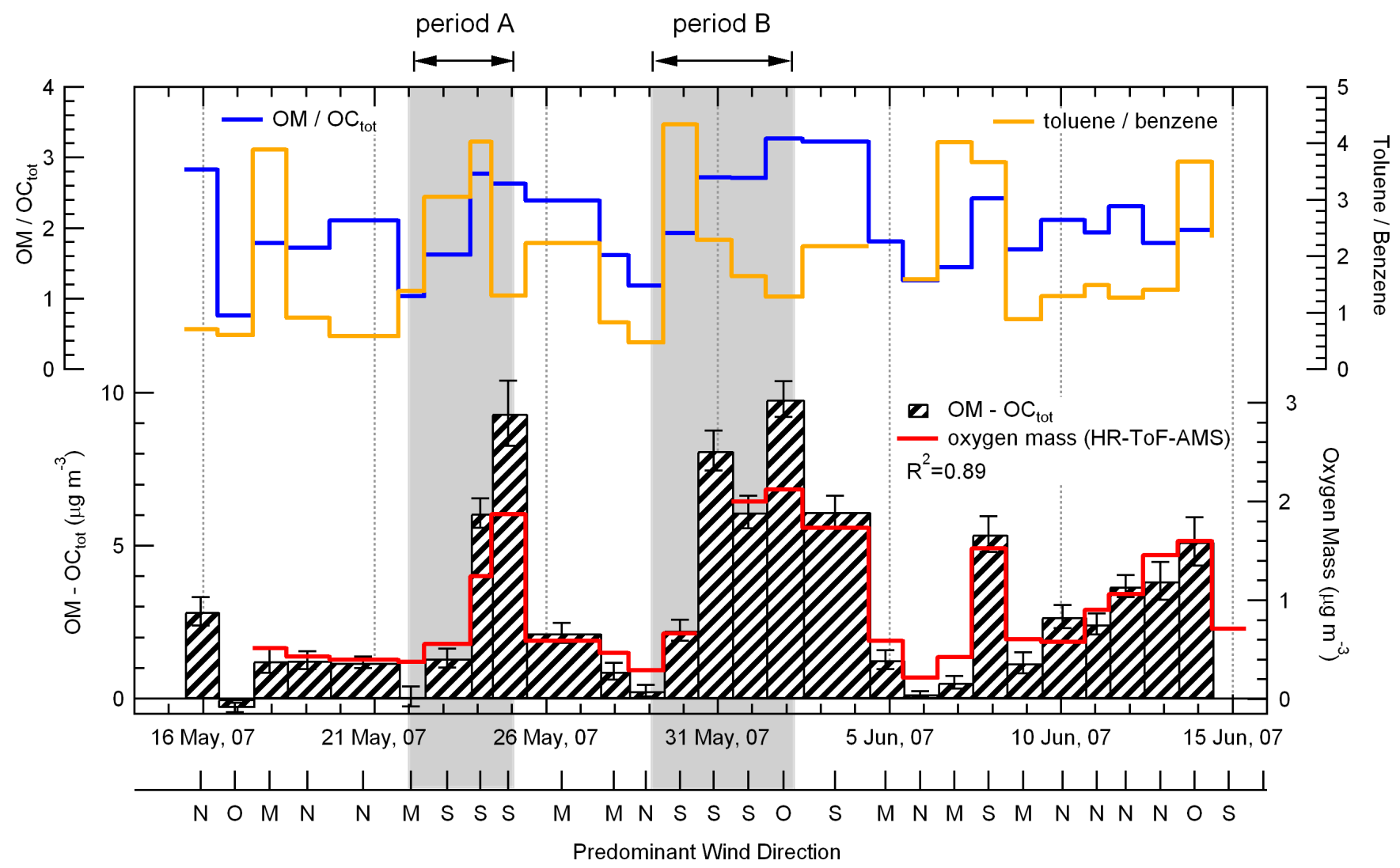

Fig. 2. The top panel shows the variations of the values of $\mathrm{OM} / \mathrm{OC}_{\text {tot }}$ and toluene/benzene for the 2007 study. Bottom panel shows the difference in mass concentration between $\mathrm{OM}$ and $\mathrm{OC}_{\text {tot }}$ (i.e., OM-OC-POC). Uncertainties are twice the standard error. Also included in the bottom panel is the oxygen mass determined from the HR-ToF-AMS. The highlighted regions are the two periods with persistent southern winds.

lifetimes, the ratio of toluene to benzene (Tol/Ben) is used as an estimate of the photochemical aging of an air mass from emission sources (e.g., Gelencsér et al., 1997), and an increase in $\mathrm{OM} / \mathrm{OC}_{\text {tot }}$ with a decrease in Tol/Ben could be an indicator for SOA formation.

The top panel in Fig. 2 shows the values of $\mathrm{OM} / \mathrm{OC}_{\text {tot }}$ (blue solid line) and the values of Tol/Ben (orange solid line); the latter are from the routine VOC measurements conducted at the CARE site (Brickell et al., 2003). In the bottom panel of the figure are the carbon excluded organic matter mass concentration estimated from the difference in mass between $\mathrm{OM}$ and $\mathrm{OC}_{\text {tot }}$ (i.e., OM-OC-POC) and the approximated oxygen mass concentration determined from the HR-TOFAMS. The HR-TOF-AMS ion fragments are quantified as $\mathrm{C}_{\mathrm{x}} \mathrm{H}_{\mathrm{y}}, \mathrm{C}_{\mathrm{x}} \mathrm{H}_{\mathrm{y}} \mathrm{O}_{\mathrm{z}}, \mathrm{C}_{\mathrm{x}} \mathrm{H}_{\mathrm{y}} \mathrm{N}_{\mathrm{j}}$, and $\mathrm{C}_{\mathrm{x}} \mathrm{H}_{\mathrm{y}} \mathrm{N}_{\mathrm{j}} \mathrm{O}_{\mathrm{z}}$, using a custom formulated algorithm (J. Liggio, personal communication; 
Table 5. The values of $\mathrm{OM} / \mathrm{OC}_{\mathrm{tot}}$ observed during the 2007 field study under heavy influence by northern and southern air masses. The value given in parenthesis is standard deviation of the mean (i.e., standard error). Also included are reference values of OM/OC observed from primary biogenic emissions dominated environments, off coast background, as well as urban environments for comparison.

\begin{tabular}{|c|c|c|c|}
\hline Data source & $\mathrm{OM} / \mathrm{OC}_{\text {tot }}$ & Comments & Predominant wind direction \\
\hline $\begin{array}{l}\text { Egbert } 2007 \text { North } \\
\text { (all data points) }\end{array}$ & $1.9( \pm 0.2)$ & $N=9$, all measurements from north & North \\
\hline $\begin{array}{l}\text { Egbert } 2007 \text { North (exclude 9- } \\
\text { 14 Jun) }\end{array}$ & $1.8( \pm 0.3)$ & $N=5$, exclude biogenic period & North \\
\hline $\begin{array}{l}\text { Egbert } 2007 \text { North } \\
\text { (only } 9-14 \text { Jun) }\end{array}$ & $2.0( \pm 0.1)$ & $N=4$, biogenic period & North \\
\hline Pio et al. (2001) & 1.5 & $\begin{array}{l}50 \text { VOC oxidation products average concen- } \\
\text { tration (primary biogenic) }\end{array}$ & $\mathrm{n} / \mathrm{a}$ \\
\hline Turpin and Lim (2001) & 1.2 & $\begin{array}{l}\text { Data from Rogge et al. (1993a) (primary bio- } \\
\text { genic) }\end{array}$ & $\mathrm{n} / \mathrm{a}$ \\
\hline Turpin and Lim (2001) & 1.3 & $\begin{array}{l}\text { Data from Rogge et al. (1993b) (off coast } \\
\text { background) }\end{array}$ & $\mathrm{n} / \mathrm{a}$ \\
\hline $\begin{array}{l}\text { Egbert } 2007 \text { South (all data } \\
\text { points) }\end{array}$ & $2.5( \pm 0.2)$ & $N=8$, all measurements from south & South \\
\hline Turpin and Lim (2001) & 1.7 & $\begin{array}{l}\text { Data from Rogge et al. (1993b) (LA down- } \\
\text { town) }\end{array}$ & $\mathrm{n} / \mathrm{a}$ \\
\hline Turpin and Lim (2001) & 1.6 & Data from Rogge et al. (1993b) (west LA) & $\mathrm{n} / \mathrm{a}$ \\
\hline Aiken et al. (2008) & 1.7 & $\begin{array}{l}\sim 2.1 \text { as Mexico City regional OM/OC from } \\
\text { aircraft }\end{array}$ & $\mathrm{n} / \mathrm{a}$ \\
\hline El-Zanan et al. (2006) & 2.1 & $\begin{array}{l}\text { An average value across the IMPROVE net- } \\
\text { work }\end{array}$ & $\mathrm{n} / \mathrm{a}$ \\
\hline
\end{tabular}

based on the work of Aiken et al., 2007, 2008). The covariance in the $\mathrm{O}$ mass concentrations (bottom panel of Fig. 2) derived from the two independent methods is relatively high $\left(R^{2}=0.89\right)$. The discrepancies in the absolute mass concentration between the carbon excluded organic matter and oxygen from the two methods may be due to several experimental uncertainties, including filter measurements, estimation of the collection efficiency (CE) of the AMS' and a reduction in the transmission efficiency (TE) of the AMS' for larger particles that may contribute significant mass at times, particularly at Egbert (Rupakheti et al., 2005). Also, the carbon excluded organic matter mass includes not only $\mathrm{O}$ mass but also masses from other atoms such as $\mathrm{N}$ and $\mathrm{H}$.

Owing to the fewer anthropogenic sources to the north, the Tol/Ben for the northern air masses is closer to unity and shows less variation relative to the southern air masses. We highlight two periods of persistent southern winds over a few days that exhibit strong variations in Tol/Ben. These periods are shaded in Fig. 2. At the beginning of each period (29 May-2 June or 22-25 May), there is a sudden switch of air masses (from north to south), a rapid increase in Tol/Ben followed by a decrease in Tol/Ben, and an increase in both $\mathrm{OM} / \mathrm{OC}_{\text {tot }}$ and the oxygen mass concentration suggests SOA formation. SOA may also be formed from the oxidations of VOCs by $\mathrm{O}_{3}$ (day and night) and $\mathrm{NO}_{3}$ (nights), which would not be strongly reflected in Tol/Ben.

\subsubsection{OM/OC ratio in the northern and southern air masses}

The values of $\mathrm{OM} / \mathrm{OC}_{\mathrm{tot}}$ and the associated predominant wind direction are shown in Fig. 3. The results are also summarized in Table 5; and the average values of $\mathrm{OM} / \mathrm{OC}_{\text {tot }}$ are $1.9 \pm 0.2$ and $2.5 \pm 0.2$ for the northern (all data) and southern air masses, respectively. The higher $\mathrm{OM} / \mathrm{OC}_{\text {tot }}$ from the south reflects contributions from both primary emissions and SOA since the oxygenated OC (POC) and OM are highly correlated with EC as well as $\mathrm{SO}_{4}^{2-}$. The $\mathrm{OM} / \mathrm{OC}_{\text {tot }}$ during the biogenic period is $2.0 \pm 0.1$, slightly higher than the average of all data from the north, and suggests relatively more SOA for that period, which is consistent with terpene oxidation. The difference in the value of $\mathrm{OM} / \mathrm{OC}_{\text {tot }}$ between the northern and the southern group may result from several factors, such as different composition of the air masses (e.g., the amounts of photochemical precursors and oxidants available) as well as the temperature difference between the two groups, which may have an effect on various atmospheric processes such as condensation, gas-to-particle partitioning, and oxidation. For comparison, Pio et al. (2001) measured the organic compounds present in the total suspended PM collected in a forest in Central Greece during July and August of 1997. Based on the 50 reported compounds that are formed by direct oxidation from VOC emitted by vegetation 


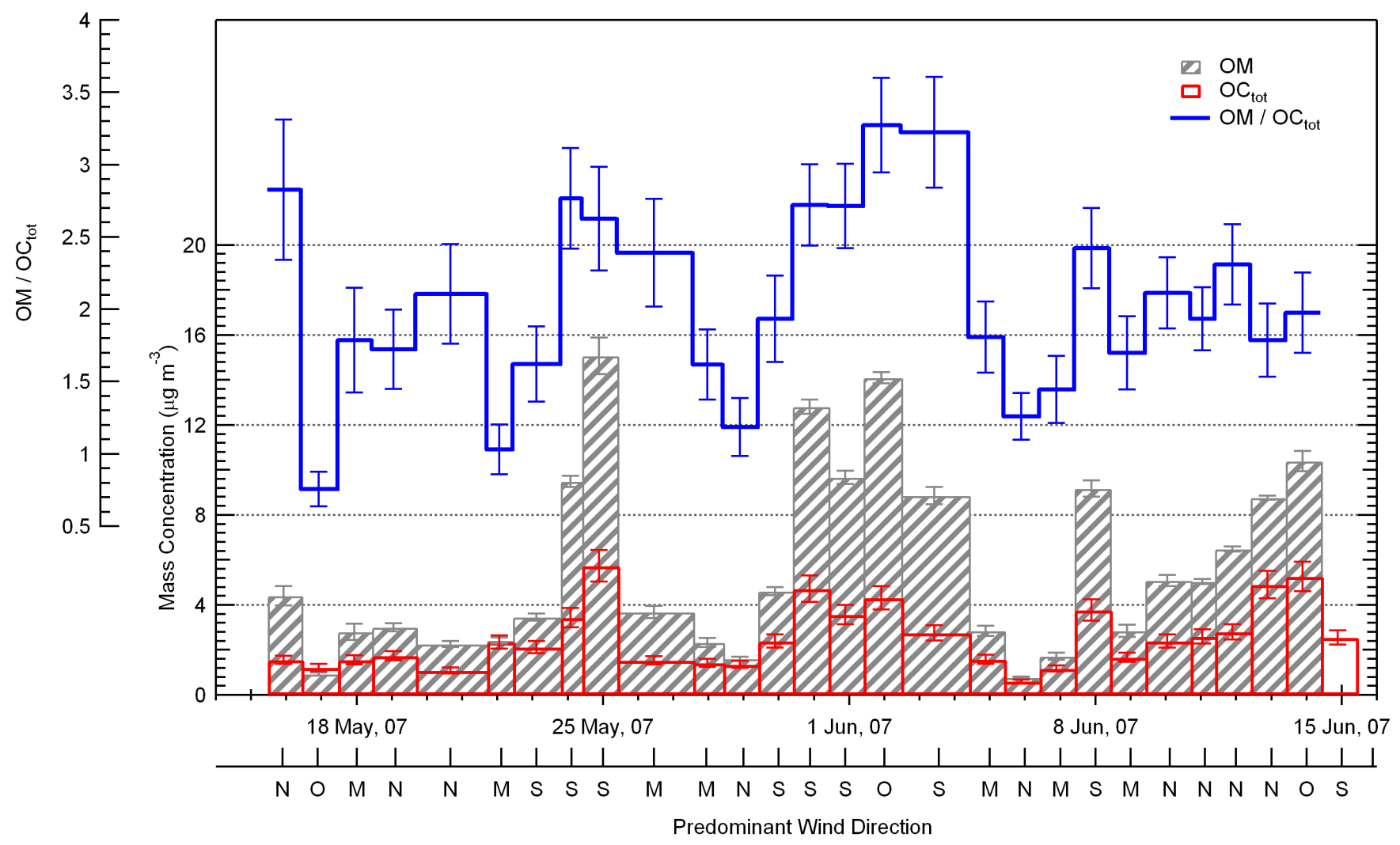

Fig. 3. The daily $\mathrm{OC}_{\text {tot }}$ concentration, integrated AMS OM measurements, and the value of OM/OC certainties are twice the standard error. Uncertainties in OM reflect only counting statistics and do not include uncertainties such as AMS transmission and collection efficiencies.

(e.g., $\alpha$-pinene and $\beta$-pinene), the concentration weighted $\mathrm{OM} / \mathrm{OC}$ was estimated to be $1.5 \pm 0.01$. The $\mathrm{OM} / \mathrm{OC}_{\text {tot }}$ values from this work are relatively higher than those reported from other studies (Table 5), although within the range of Table 1, which might reflect differences in measurement techniques, unique conditions at the CARE location, or combination of both.

Possible uncertainties in the values of $\mathrm{OM} / \mathrm{OC}_{\text {tot }}$ arise from a number of sources:

- The averaging of OM measurements over occasional data gaps due to periods of zero checks, switching measurement modes and instrumental problems (Slowik et al., 2009) will result in random biases in the $\mathrm{OM} / \mathrm{OC}_{\text {tot }}$ during periods of significant changes in the atmospheric compositions;

- OM will be underestimated relative to the filter OC when the OM mass concentration between the upper end of the AMS TE and the cyclone used in the filter measurements is significant, i.e., $\sim 500 \mathrm{~nm}$ to $1 \mu \mathrm{m}$;

- The estimated AMS CE does not sufficiently represent the $\mathrm{CE}$ for the entire size distribution due to the different compositions of the aerosol particles at different particle sizes (Slowik et al., 2009);

- OC contamination of the sample filters due to transportation and/or handling during sampling or analysis, outside of the blank correction;

- OC artefacts from condensation during sampling as well as reduction in OC due to evaporation during the sampling (Turpin et al., 2000; Viana et al., 2006).

\subsubsection{Estimation of the OM/OC ratios from POC}

Huang et al. (2006) found that the concentration of POC determined was related to the amount of oxygen mass in the standards (e.g., no POC fraction was identified in pure OC compounds and POC was identified in sucrose and glucose) with a thermal method very similar to the one used here. The $\mathrm{OM} / \mathrm{OC}$ ratio can be derived as

$$
\begin{aligned}
& \frac{\mathrm{OM}}{\mathrm{OC}}=\frac{\mathrm{C}_{\text {mass }}+\mathrm{O}_{\text {mass }}+\mathrm{N}_{\text {mass }}+\mathrm{H}_{\text {mass }}+\ldots}{\mathrm{C}_{\text {mass }}} \\
& \frac{\mathrm{OM}}{\mathrm{OC}}=1+\frac{\mathrm{O}_{\text {mass }}+\mathrm{N}_{\text {mass }}+\mathrm{H}_{\text {mass }}+\ldots}{\mathrm{C}_{\text {mass }}}
\end{aligned}
$$




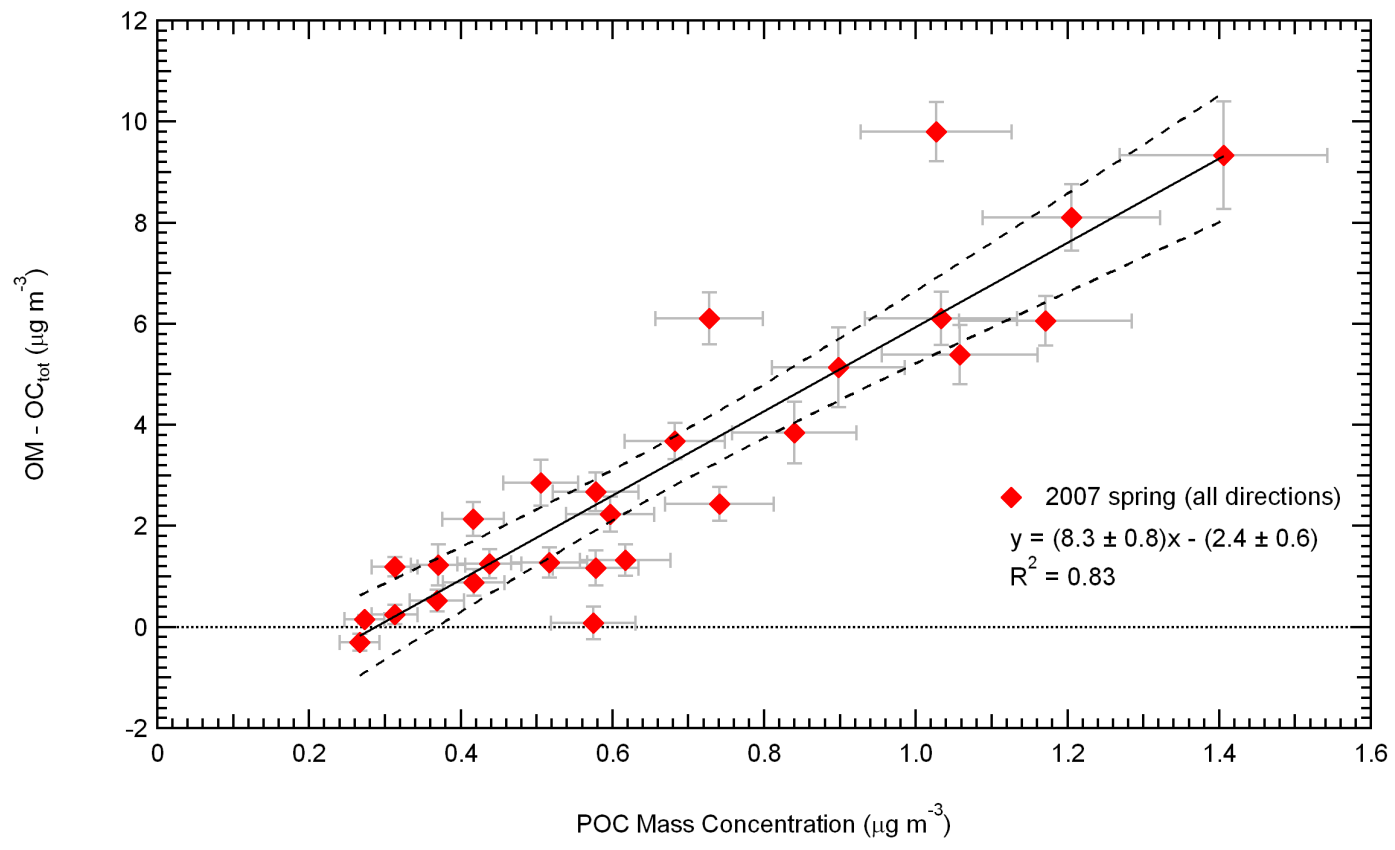

Fig. 4. Relationship between the carbon excluded organic matter mass (i.e., OM-OC study. Uncertainties are twice the standard error. Solid line is the least squares best fit for all data. Dotted curves represent $95 \%$ confidence interval bands.

Figure 4 shows the relationship between the POC and the carbon excluded organic matter mass (i.e., $\mathrm{OM}-\mathrm{OC}_{\text {tot }}$ or OM-OC-POC). Note that the carbon excluded organic matter mass includes not only $\mathrm{O}$ mass but also masses from atoms such as $\mathrm{N}$ and $\mathrm{H}$, this is equivalent to the numerator of the right side of the equality in Eq. (1). The relationship between the $\left(\mathrm{OM}-\mathrm{OC}_{\text {tot }}\right)$ and POC in Fig. 4 is wind direction independent suggesting that this is more a result of the measurement technique than the type of aerosol. More supporting information is given in Fig. 5 for better understanding the relationship between POC and other measured quantities. Figure $5 \mathrm{a}$ shows the relationship between the POC mass and the estimated O mass from HR-ToF-AMS; this suggests that the POC mass, defined as the carbon fraction released from 550 to $870^{\circ} \mathrm{C}$, is indeed related to the oxygenated compounds in the aerosols. Figure $5 \mathrm{~b}$ shows the relationship between the POC mass and the $m / z 44$ to total organics mass ratio. The $\mathrm{m} / \mathrm{z} 44$ to total organics mass ratio is a general indicator of the relative oxygen content in the total organic matter mass measured from the C-ToF-AMS and it reflects the degree of atmospheric oxidation in the measured aerosols. Together with Fig. 5a, these results show that the increase in oxygen content in the aerosols due to processing can be reflected on the POC mass determined from the current thermal method. The result in Fig. 4 provides an empirical solution to estimate the carbon excluded organic matter mass concentration in the ambient aerosols based on just the thermal measurements of POC and OC. Substitute this relationship into Eq. (1) yields the $\mathrm{OM} / \mathrm{OC}$ ratio,
$\mathrm{OM} / \mathrm{OC} \approx 1+\frac{(8.3 \pm 0.8) \times \mathrm{POC}-(2.4 \pm 0.6)}{\mathrm{OC}+\mathrm{POC}}$

for $\quad P O C \geq 0.29$

Note that base on the results from this study, Eq. (2) is only valid for POC mass equal or larger than $0.29 \mu \mathrm{g} \mathrm{m}^{-3}$ as a minimum mass load on the filter is required in order to get accurate measure of the POC mass. The quantities "OC" and "POC" on the right side of the equation are defined in Sect. 2.2.1 and obtained by the thermal method (EnCan_Total-900). Also, since the POC in the current thermal method is defined differently than other thermal/optical methods, such as IMPROVE and NIOSH, the above relationship may not be valid for other thermal/optical method unless the relationship between the POC determined from the different methods has been established.

\subsection{SAC and particle mass loading}

\subsubsection{SAC at Egbert}

The particle light absorption coefficient $\left(b_{\text {asp }}\right)$ increases with the EC mass concentration (Fig. 6). The data are split between the northern and southern air masses as represented by the blue triangles and red squares, respectively, and the size of the marker is scaled to represent the amount of particle mass loading, defined as the sum of $\mathrm{OM}$, sulphate, and nitrate mass concentrations. The slope of the north data is slightly lower than that of the south data, but since the numbers of data points are relatively low we can not say that the 

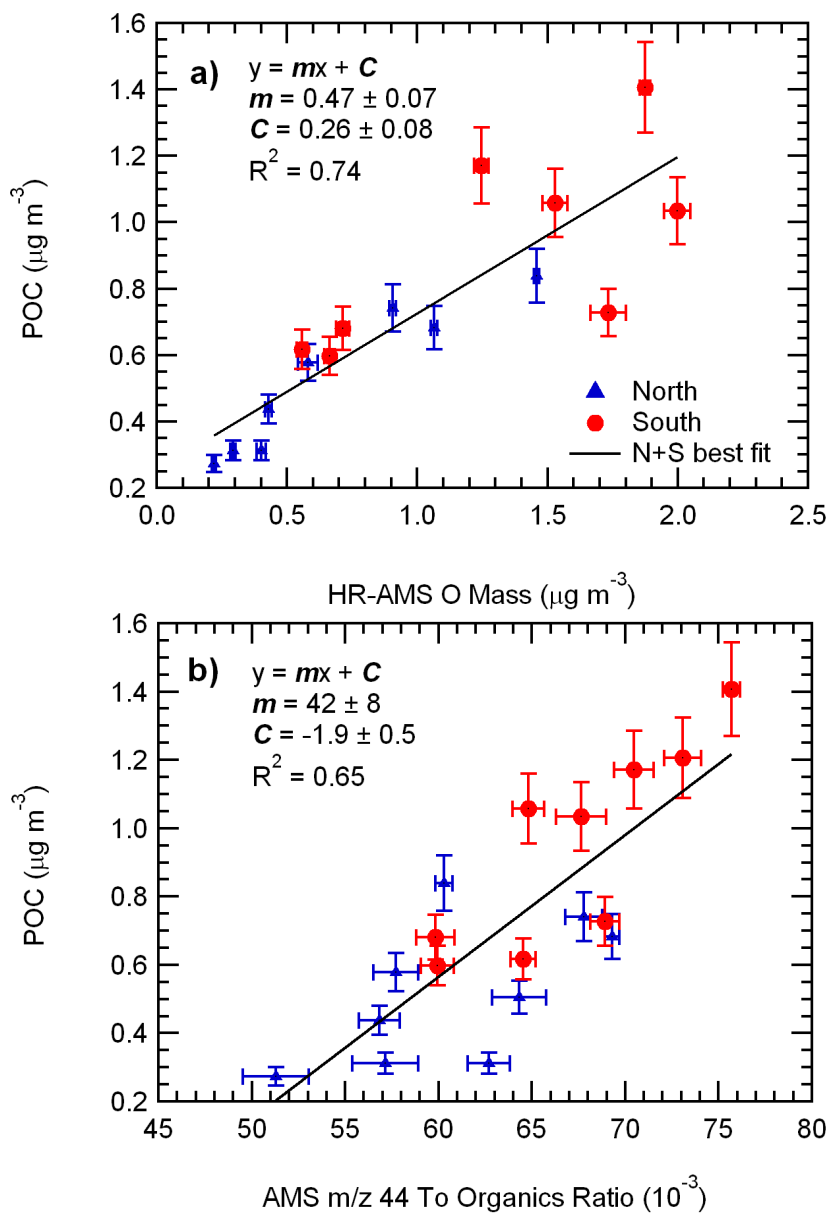

Fig. 5. (a) Relationship between the POC mass and the oxygen mass estimated from the HR-ToF-AMS. (b) Relationship between the POC mass and the $m / z 44$ to total organics mass ratio. The error bars cover twice of the standard error (confidence level: 95\%).

slopes differ with a high level of confidence. The slope of the ordinary least squares regression for the combined north and south data is $3.8 \pm 0.3 \mathrm{~m}^{2} \mathrm{~g}^{-1}$, which is within the SAC range of 3.5-5.0 $\mathrm{m}^{2} \mathrm{~g}^{-1}$ reported by Sharma et al. (2002) for Egbert.

\subsubsection{Relationship between SAC and particle mass loading}

It is widely believed that the SAC will increase with particle coating (e.g., Bond and Bergstrom, 2006; Bond et al., 2006). We consider this through comparison of the SAC with the particle mass loading as represented by the sum of sulphate, nitrate and OM measured with the AMS (Fig. 7). We do not have direct evidence that the EC is internally mixed with the sulphate, nitrate and SOA, but since most of the sulphate and nitrate and at least some of the $\mathrm{OM}$ are formed by secondary processes, it reasonable to conclude that the $\mathrm{BC}$ was increasingly coated as the mass loading increased. Figure 8a shows the variations of the $\mathrm{m} / \mathrm{z} 44$ to total organics mass ratio as a function of particle mass loading. The relationship reveals that the two quantities are positively correlated, supporting the contention that photochemical oxidation played an important role in the variations of the particle mass loading for both south and north air masses. Although some of the oxygenated OM may be primary, Fig. 8a suggests that the use of particle mass loading as a surrogate for increasing atmospheric oxidation at this rural site is reasonable. As for the relationship between the SAC and particle mass loading (Fig. 7), the slope for the northern air masses is $-0.2 \pm 0.1$ while the slope for the southern air masses is $-0.1 \pm 0.0$. The slope of the combined north and south measurements is nearer zero $(-0.01 \pm 0.0)$. As the ordinary least squares fit assumes the independent variable (particle mass loading in this case) is error free, the geometric mean regression slopes for the north and south data groups are also calculated using the method of Zobitz et al. (2006). The geometric mean regression slope is estimated by the ratio of the ordinary least squares regression slope to the absolute value of the correlation coefficient between the SAC and the amount of particle mass loading. The geometric mean regression slopes for the northern and southern air masses are -0.3 and -0.1 , respectively, indicating that the value of SAC at this rural site does not increase with the particle mass loading. Information in Fig. 8 provides further support. Figure $8 \mathrm{~b}$ shows the variations of the $\mathrm{SAC}$ as a function of the estimated $\mathrm{O}$ mass measured from the HR-ToF-AMS. SAC values from the north and the south show slightly decreasing trends with increasing oxygen mass. In Fig. 8c, the value of SAC also shows a negative relationship with increasing value in the $\mathrm{m} / \mathrm{z} 44$ to total organics mass ratio.

We separate the data between north and south because the sources and processes dominating the particles can be significantly different. The aerosol arriving from the north is much less dominated by recent source anthropogenic input and has relatively stronger contributions from natural sources (e.g., biogenic). The mass concentrations of all components are low (Table 3) relative to those from the south, indicating the limitation of source strength. The particles in the northern air masses, particularly the black carbon (BC) component, i.e., the light absorption carbon, tend to have been transported over longer distances and resided for a longer time in the atmosphere. In contrast, much of the $\mathrm{BC}$ and secondary material (e.g., sulphate, nitrate, $\mathrm{OM}$ ) is more recent due to the proximity of the urban and industrial areas over Toronto and the northeast of United States. Temperatures accompanying the northern aerosols are cooler, which can enhance nucleation and condensation but the levels of precursors and oxidants in the northern air are much lower. Higher temperatures with the southern air masses could promote photochemical oxidations. Regardless of whether the data are separated between north and south, there is nothing to indicate an enhancement in the particle light absorption due to the coating 


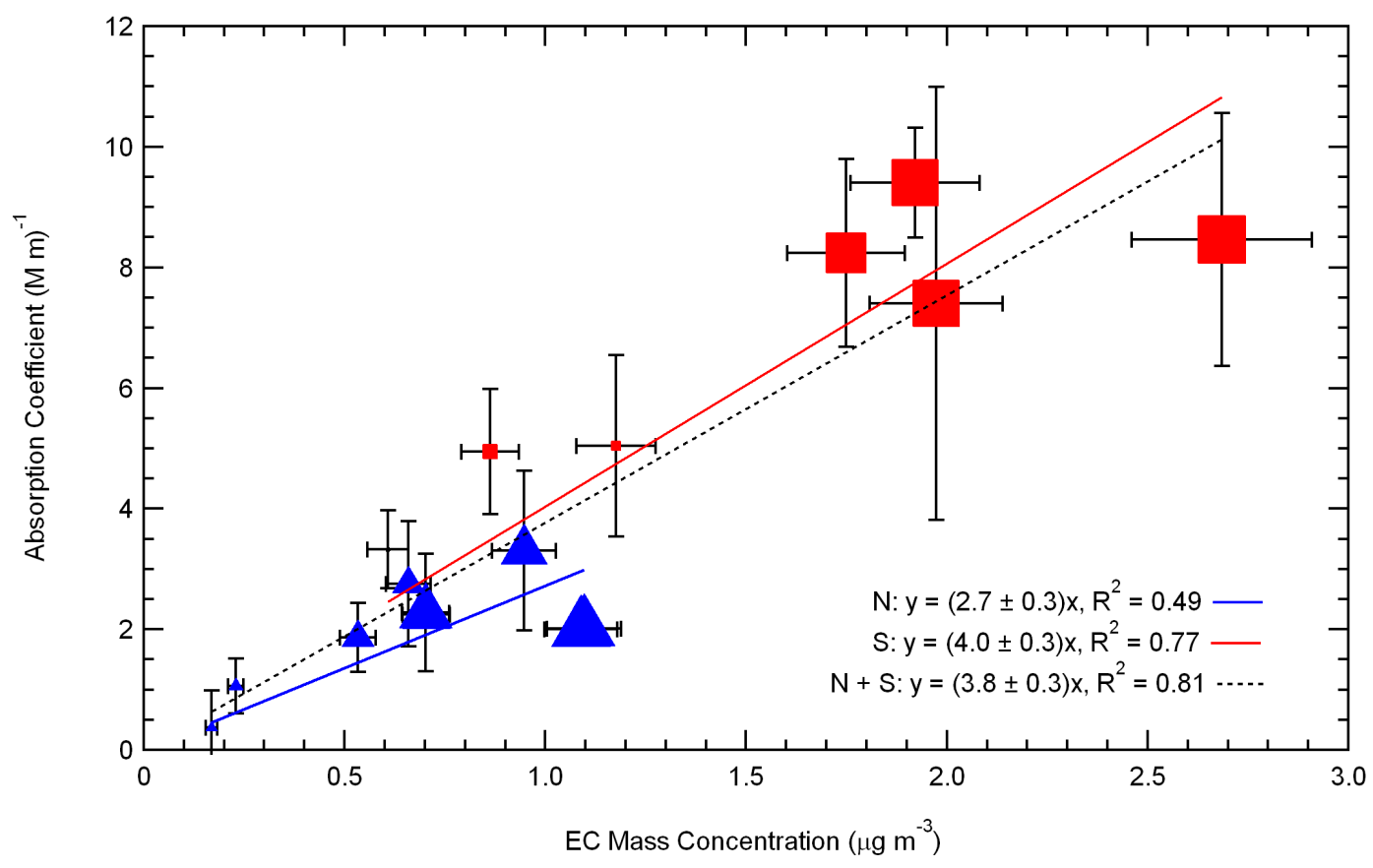

Fig. 6. Relationship between the $b_{\text {asp }}$ and the EC for the 2007 study. The data for the northern air masses are given in blue triangles while the data for the southern air masses are given in red squares. Uncertainties are twice the standard error. The size of the marker represents the amount of particle mass loading defined as the sum of OM, sulphate, and nitrate mass concentrations. Various lines represent the ordinary least squares fit line for various sub data sets.

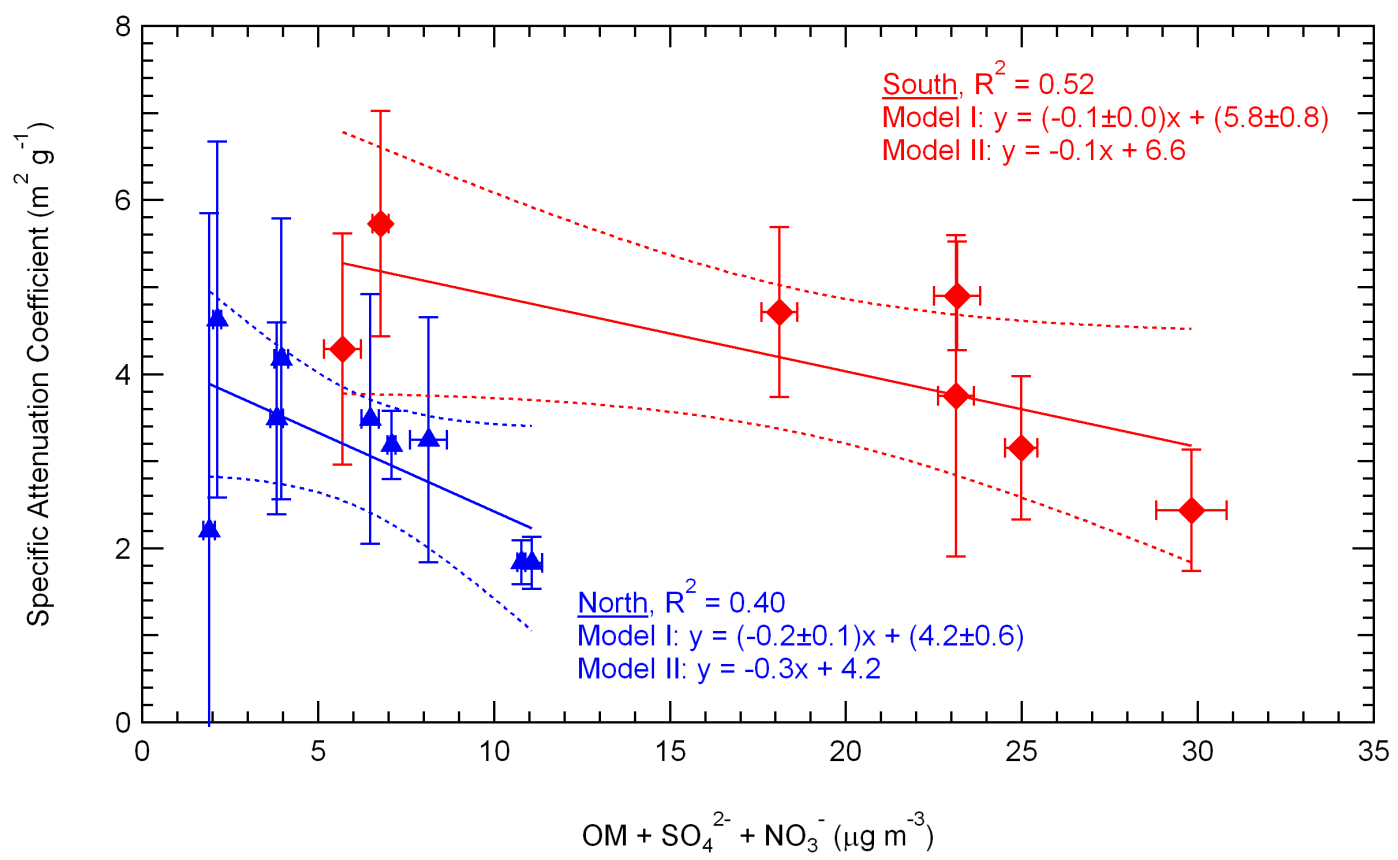

Fig. 7. Relationship between the specific attenuation coefficient (SAC) and the amount of particle mass loading, defined as the sum of OM, sulphate, and nitrate mass concentrations, at Egbert for the northern (blue triangles) and southern (red diamonds) air masses. Uncertainties are twice the standard error. Solid line represents the ordinary least squares fit line and the dotted curves represent the $95 \%$ confident interval bands. Model I: the ordinary least squares regression; Model II: the geometric mean regression. 

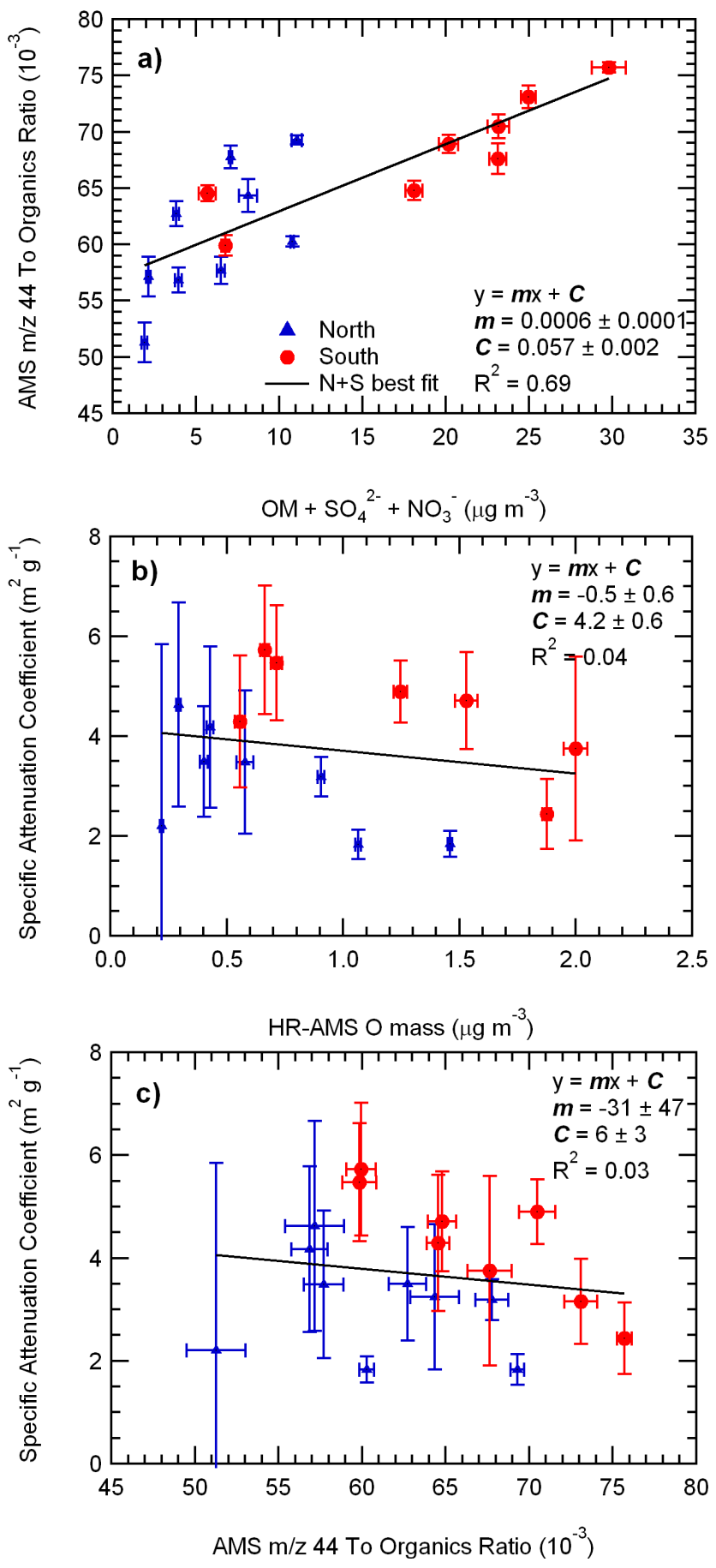

Fig. 8. (a) Relationship between the $m / z 44$ to total organics mass ratio and particle mass loading. (b) Relationship between the SAC and the oxygen mass estimated from the HR-ToF-AMS. (c) Relationship between the SAC and the $m / z 44$ to total organics mass ratio. The error bars cover twice of the standard error (confidence level: 95\%).

of secondary materials on soot (Bond and Bergstrom, 2006; Bond et al., 2006) at this rural site. The degree of potential enhancement in light absorption depends on factors such as the position of the soot particle within the coating (Fuller et al., 1999), the amount and refractive index of the coating materials (Fuller et al., 1999; Slowik et al., 2007) and also the different BC sources.

Many global models enhance light absorption by BC particles due to coating by secondary components (e.g., Jacobson, 2001; Chung and Seinfeld, 2002; Kim et al., 2008). The present results, indicating a neutral or negative relationship between the SAC and the amount of particle mass loading, suggest that light absorption by BC may not be enhanced with increasing processing in the atmosphere. Collapse of the soot particle aggregates related to accumulation of secondary material has been suggested as a possible mechanism for a reduction in the SAC (Lewis et al., 2009; Liousse et al., 1993; Bond and Bergstrom, 2006; Fuller et al., 1995; Iskander et al., 1991), although numerical calculations show that soot collapse may either decrease or increase light absorption by $10 \%$ or less (Liu et al., 2008). It is possible that the particles observed here are not included in the parameter space explored by Liu et al. (2008). An increase in the soot particle diameter can lead to a decrease in SAC (Bond et al., 2006; Bond and Bergstrom, 2006; Dillner et al., 2001) and chemical transformation of soot over time may also have an affect on the soot mass concentration (Decesari et al., 2002).

There is no evidence to indicate that artefacts in the PSAP measurements led to the negative relationship between the $\mathrm{SAC}$ and sulphate+nitrate $+\mathrm{OM}$. The potential issues with the PSAP measurements are as follows:

1. loading corrections, which have been applied following Bond et al. (1999) and are correct to as applied within a few \% (Virkkula et al., 2005),

2. single scattering albedo corrections (Virkkula et al., 2005) have not been applied here as Schmid et al. (2006) did not found them necessary. Applying such correction should further decrease the current absorption values for increasing single scattering albedo caused by increasing the total aerosol mass loading,

3. high humidities have been reported to increase reported PSAP absorption (Arnott et al., 2003; Sedlacek and Lee, 2007) but the correction algorithm suggested by Schmid et al. (2006) has not been used here, However, integrating the relative humidity measurements over the same filter sampling period gives an average value of $34.6 \%$ $(\mathrm{SD}=8.8 \%)$.

4. artefacts due to high $\mathrm{OC}$ and POC concentrations have been reported to increase PSAP readings proportional to OC concentrations (Cappa et al., 2008; Lack et al., 2008), which does not seem to be the case in Fig. 7.

Owing to the influences from both long and mid range transport, the absence of a positive relationship between SAC and 
the particle mass loading (Fig. 7) may be the result of several factors, including an increase in soot particle diameter due to coagulation at high mass concentrations in a plume, collapse of the primary soot particle structure with increased mass concentrations, and chemical transformation of soot with time. Also, there may be a contribution from changes in absorption by materials in the OM (i.e. brown carbon, Kirchstetter, 2004). Temperature differences between the northern and southern air masses may play a role in enhancing photochemical processes, affecting processes such as condensation and gas-to-particle partitioning, but the temperatures in the northern air mass during the biogenic period were unusually high (Slowik et al., 2009).

\section{Future work}

These somewhat unexpected results reflect the complexity in predicting aerosol light absorption of atmospheric $\mathrm{BC}$ when a number of factors are contributing simultaneously. Further examination of this requires:

- A need to measure BC inclusions smaller than $100 \mathrm{~nm}$.

- A need to determine the mixing state of the ambient aerosol.

- The study of light extinction by particles as BC is increasingly coated by light scattering materials.

- A need to determine the relationship between the POC or charred OC mass concentrations with different types of oxygenated organic compounds (e.g. humic-like substances, organic sulfates, organic nitrates) to improve quantification of POC.

\section{Conclusions}

The values of $\mathrm{OM} / \mathrm{OC}_{\text {tot }}$ for ambient fine particles collected at a rural site from an intensive study in 2007 spring were determined based on the OM measured with C-ToFAMS and OC determined from quartz filters by a thermal analysis. Due to the impacts by different sources and other temperature-induced atmospheric processes, the average value of $\mathrm{OM} / \mathrm{OC}_{\text {tot }}$ for the south and north air masses were found to be $2.5 \pm 0.2$ and $1.9 \pm 0.2$, respectively. The air masses from the south (i.e., strongly influenced by anthropogenic emissions within 1-2 days of observation) generally contained lower values of OC/EC, higher mass concentrations of $\mathrm{EC}$ and sulphate, and higher values of $\mathrm{OM} / \mathrm{OC}_{\text {tot }}$. The higher $\mathrm{OM} / \mathrm{OC}_{\text {tot }}$ values from the south may imply the impacts from both primary emissions and secondary OM formations as the oxygenated $\mathrm{OC}$ (POC) and $\mathrm{OM}$ are highly correlated with $\mathrm{EC}$ as well as $\mathrm{SO}_{4}^{2-}$. In contrast, the air masses from the north (i.e., more influenced by biogenic emissions or by the components with longer residence time) generally had higher values of OC/EC, lower mass concentrations of EC and sulphate, and lower values of OM/OC. The air masses from the north are generally much cooler than the air masses from the south although an increase in temperature was also observed during the biogenic period from the north. Although the temperature induced processes could not be ignored (e.g. cooler temperature enhancing nucleation and condensation vs. warmer temperature promoting photochemical reaction), the difference in emission sources and their strength likely play important roles in the variation of aerosol compositions at the site.

The mass concentrations of POC determined from the thermal filter method were proportional to the carbon excluded organic mass (which is dominated by oxygen mass) in the particles $\left(\mathrm{OM}-\mathrm{OC}_{\mathrm{tot}}\right)$. The relationship was found to be independent of wind direction, suggesting it as a possible means of estimating values of OM/OC in PM via the use of thermal measurements only.

Values of the SAC of the ambient aerosol particles were estimated based on the $b_{\text {asp }}$ measured with a PSAP and the EC determined from the thermal method. The mean SAC for the spring 2007 observations is $3.8 \pm 0.3 \mathrm{~m}^{2} \mathrm{~g}^{-1}$. The SAC was examined in relation to the sum of the mass concentrations of sulphate, nitrate and OM. Regardless of whether the data are separated between north and south, there is nothing to indicate an enhancement in the particle light absorption due to the coating of secondary materials on soot as suggested by others (e.g. Bond and Bergstrom, 2006; Bond et al., 2006). We can not draw any conclusions as to the reasons for this, but our observations indicate that the absorption of light by soot with increasing levels of secondary materials, including organic materials and sulphate, is more complicated than that currently represented in models and requires considerable investigation.

Acknowledgements. Authors sincerely thank many Environment Canada employees for supporting this work. Specifically, Jan Bottenheim for providing the toluene and benzene data, Dave Halpin for collecting the quartz filter samples during the two field studies, Wendy Zhang for performing the OC/EC measurements, Nicole Shantz for help with the simulations, and Senen Racki for providing the wind speed and wind direction data. Ambient temperature measurements at CARE were obtained through the Environment Canada Data Collection Platform. Partial funding for the Egbert 2007 study came from CFCAS. Funding for the AMS came to SOCAAR from CFI and OIT. Financial support for Tak W. Chan came from Environment Canada through Natural Sciences and Engineering Research Council (NSERC) postdoctoral visiting fellowship. Authors would like to thank the three anonymous reviewers for their helpful comments to have this paper improved greatly.

Edited by: M. Petters 


\section{References}

Aiken, A. C., DeCarlo, P. F., and Jimenez, J. L.: Elemental analysis of organic species with electron ionization high-resolution mass spectrometry, Anal. Chem., 79, 8350-8358, 2007.

Aiken, A. C., DeCarlo, P. F., Kroll, J. H., Worsnop, D. R., Huffman, J. A., Docherty, K. S., Ulbrich, I. M., Mohr, C., Kimmel, J. R., Sueper, D., Sun, Y., Zhang, Q., Trimborn, A., Northway, M., Ziemann, P. J., Canagaratna, M. R., Onasch, T. B., Alfarra, M. R., Prevot, A. S. H., Dommen, J., Duplissy, J., Metzger, A., Baltensperger, U., and Jimenez, J. L.: O/C and OM/OC ratios of primary, secondary, and ambient organic aerosols with highresolution Time-of-Flight Aerosol Mass Spectrometry, Environ. Sci. Technol., 42, 4478-4485, 2008.

Alfarra, M. R., Paulsen, D., Gysel, M., Garforth, A. A., Dommen, J., Prévôt, A. S. H., Worsnop, D. R., Baltensperger, U., and Coe, H.: A mass spectrometric study of secondary organic aerosols formed from the photooxidation of anthropogenic and biogenic precursors in a reaction chamber, Atmos. Chem. Phys., 6, 52795293, 2006,

http://www.atmos-chem-phys.net/6/5279/2006/.

Allan, J. D., Jimenez, J. L., Williams, P. I., Alfarra, M. R., Bower, K. N., Jayne, J. T., Coe, H., and Worsnop, D. R.: Quantitative sampling using an Aerodyne Aerosol Mass Spectrometer, 1, Techniques of Data Interpretation and Error Analysis, J. Geophys. Res., 108(D3), 4090, 2003. doi:10.1029/2002JD002358.

Alves, C., Pio, C., Carvalho, A., and Santos, C.: Atmospheric carbonaceous aerosols over grasslands of central Europe and a Boreal forest, Chemosphere, 63, 153-164, 2006.

Arnott, W. P., Moosmüller, H., Sheridan, P. J., Ogren, J. A., Raspet, R., Slaton, W. V., Hand, J. L., Kreidenweis, S. M., and Collett Jr., J. L.: Photoacoustic and filter-based ambient aerosol light absorption measurements: instrument comparison and the role of relative humidity, J. Geophys. Res., 108, 4034-4044, doi:10.1029/2002JD002165, 2003.

Atkinson, R.: Gas-phase tropospheric chemistry of organic compounds: a review, Atmos. Environ. - Part A, 24A, 1-41, 1990.

Bae, M. S., Demerjian, K. L., and Schwab, J. J.: Seasonal estimation of organic mass to organic carbon in $\mathrm{PM}_{2.5}$ at rural and urban locations in New York state, Atmos. Environ., 40, 7467-7479, 2006.

Bahadur, R., Habib, G., and Russell, L. M.: Climatology of PM2.5 organic carbon concentrations from a review of ground-based atmospheric measurements by evolved gas analysis, Atmos. Environ., 43, 1591-1602, 2009.

Bond, T. C., Anderson, T. L., and Campbell, D.: Calibration and intercomparison of filter-based measurements of visible light absorption by aerosols, Aerosol Sci. Technol., 30, 582-600, 1999.

Bond, T. C. and Bergstrom, R. W.: Light absorption by carbonaceous particles: an investigative review, Aerosol Sci. Technol., 40, 27-67, 2006.

Bond, T. C., Habib, G., and Bergstrom, R. W.: Limitations in the enhancement of visible light absorption due to mixing state, J. Geophys. Res., 111, D20211, doi:10.1029/2006JD007315, 2006.

Brickell, P. C., Bottenheim, J. W., Froude, F., and Jiang, Z.: Continuous in-situ NMHC measurements in rural Ontaio, Canada, Eos. Trans. AGU, 84(46), Fall Meeting Suppl., Abstract A31D-0070, 2003.

Cabada, J. C., Pandis, S. N., and Robinson, A. L.: Sources of atmospheric carbonaceous particulate matter in Pittsburgh, Pennsyl- vania, J. Air Waste Manage. Assoc., 52, 732-741, 2002.

Cabada, J. C., Pandis, S. N., Subramanian, R., Robinson, A. L., Polidori, A., and Turpin, B.: Estimating the secondary organic aerosol contribution to $\mathrm{PM}_{2.5}$ using the EC tracer method, Aerosol Sci. Technol., 38(S1), 140-155, 2004.

Cachier, H., Brémond, M. P., and Buat-Ménard, P.: Determination of atmospheric soot carbon with a simple thermal method, Tellus, 41B, 379-390, 1989a.

Cachier, H., Brémond, M. P., and Buat-Ménard, P.: Thermal separation of soot carbon, Aerosol Sci. Technol., 19, 358-364, 1989b.

Cappa, C. D., Lack, D. A., Burkholder, J. B., and Ravishankara, A. R.: Bias in filter-based aerosol light absorption measurements due to organic aerosol loading: evidence from laboratory measurements, Aerosol Sci. Technol., 42, 1022-1032, 2008.

Chan, T. W. and Mozurkewich, M.: Application of absolute principal component analysis to size distribution data: identification of particle origins, Atmos. Chem. Phys., 7, 887-897, 2007, http://www.atmos-chem-phys.net/7/887/2007/.

Cheng, M. T. and Tsai, Y. I.: Characterization of visibility and atmospheric aerosols in urban, suburban, and remote areas, Sci. Total Environ., 263, 101-114, 2000.

Chow, J. C., Watson, J. G., Pritchett, L. C., Pierson, W. R., Frazier, C. A., and Purcell, R.G.: The DRI thermal/optical reflectance carbon analysis system: description, evaluation and applications in U.S. air quality studies, Atmos. Environ., 27A, 1185-1201, 1993.

Chow, J. C., Watson, J. G., Crow, D., Lowenthal, D. H., and Merrifield, T.: Comparison of IMPROVE and NIOSH carbon measurements, Aerosol Sci. Technol., 34, 23-34, 2001.

Chung, S. H. and Seinfeld, J. H.: Global distribution and climate forcing of carbonaceous aerosols, J. Geophys. Res., 107, 4407, doi:10.1029/2001JD001397, 2002.

de Gouw, J. A., Middlebrook, A. M., Warneke, C., Goldan, P. D., Kuster, W. C., Roberts, J. M., Fehsenfeld, F. C., Worsnop, D. R., Canagaratna, M. R., Pszenny, A. A. P., Keene, W. C., Marchewka, M., Bertman, S. B., and Bates, T. S.: Budget of organic carbon in a polluted atmosphere: results from the New England Air Quality Study in 2002, J. Geophys. Res., 110, D16305, doi:10.1029/2004JD005623, 2005.

Decesari, S., Facchini, M. C., Matta, E., Mircea, M., Fuzzi, S., Chughtai, A. R., and Smith, D. M.: Water soluble organic compounds formed by oxidation of soot, Atmos. Environ., 36, 18271832, 2002.

Dillner, A. M., Stein, C., Larson, S. M., and Hitzenberger, R.: Measuring the mass extinction efficiency of elemental carbon in rural aerosol, Aerosol Sci. Technol., 35, 1009-1021, 2001.

Dockery, D. W., Schwartz, J., and Spengler, J. D.: Air pollution and daily mortality: associations with particulates and acid aerosols, Environ. Res., 59, 362-373, 1992.

Drewnick, F., Hings, S. S., DeCarlo, P., Jayne, J. T., Gonin, M., Fuhrer, K., Weimer, S., Jimenez, J. L., Demerjian, K. L., Borrmann, S., and Worsnop, D. R.: A new time-of-flight Aerosol Mass Spectrometer (TOF-AMS) - instrument description and first field deployment, Aerosol Sci. Technol., 39, 637-358, 2005.

El-Zanan, H. S., Lowenthal, D. H., Zielinska, B., Chow, J. C., and Kumar, N.: Determination of the organic aerosol mass to organic carbon ratio in IMPROVE samples, Chemosphere, 60, 485-496, 2005.

Fehsenfeld, F., Calvert, J., Fall, R., Goldan, P., Guenther, A. B., 
Hewitt, C. N., Lamb, B., Liu, S., Trainer, M., Westberg, H., and Zimmerman, P.: Emissions of volatile organic compounds from vegetation and the implications for atmospehric chemistry, Global Biogeochem. Cycles, 6, 389-430, 1992.

Fraser, M. P., Cass, G. R., and Simoneit, B. R. T.: Gas-phase and particle-phase organic compounds emitted from motor vehicle traffic in a Los Angeles roadway tunnel, Environ. Sci. Technol., 32, 2051-2060, 1998.

Fuller, K. A., Malm, W. C., and Kreidenweis, S. M.: Effects of mixing on extinction by carbonaceous particles, J. Geophys. Res., 104, 15941-15954, 1999.

Gelencsér, A., Siszler, K., and Hlavay, J.: Toluene-benzene concentration ratio as a tool for characterizing the distance from vehicular emission sources, Environ. Sci. Technol., 31, 2869-2872, 1997.

Gelencsér, A.: Methods of observation of carbonaceous aerosol, in Carbonaceous aerosol, Ch. 2, pp. 7-44, Springer, Netherlands, 2004.

Gray, H. A.: Control of atmospheric fine primary carbon particle concentrations, EQL Report No. 23, Environmental Quality Laboratory, California Institute of Technology, Pasadena, CA, pp. 103-108, 1986

Grosjean, D. and Friendlander, S. K.: Gas-particle distribution factors for organic and other pollutants in the Los Angeles atmosphere, J. Air Pollut. Control Assoc., 25, 1038-1044, 1975.

Han, Y., Cao, J., Chow, J. C., Watson, J. G., An, Z., Jin, Z., Fung, K., Liu, S.: Evaluation of the thermal/optical reflectance method for discrimination between char- and soot-EC, Chemosphere, 69 , 569-574, 2007.

Hildemann, L. M., Rogge, W. F., Cass, G. R., Mazurek, M. A., and Simoneit, B. R. T.: Contribution of primary aerosol emission from vegetation-derived sources to fine particle concentrations in Los Angeles, J. Geophys. Res., 101, 19541-19549, 1996.

Hoffmann, T., Bandur, R., Marggraf, U., and Linscheid, M.: Molecular composition of organic aerosols formed in the $\alpha$-pinene $/ \mathrm{O}_{3}$ reaction: implications for new particle formation processes, $\mathrm{J}$. Geophys. Res., 103, 25569-25578, 1998.

Horvath, H.: Atmospheric light absorption-a review, Atmos. Environ., 27A, 293-317, 1993.

Huang, L., Brook, J. R., Zhang, W., Li, S. M., Graham, L., Ernst, D., Chivulescu, A., and Lu, G.: Stable isotope measurements of carbon fractions (OC/EC) in airborne particulate: a new dimension for source characterization and apportionment, Atmos. Environ., 40, 2690-2705, 2006.

Huntzicker, J. J., Johnson, R. L., Shah, J. J., and Cary, R. A.: Analysis of organic and elemental carbon in ambient aerosols by a thermal-optical method, in Particulate carbon - atmospheric life cycle, edited by: Wolff, G. T. and Klimisch, R. L., pp.79-88, Plenum Press, New York, 1982.

Iskander, M. F., Chen, H. Y., and Penner, J. E.: Resonance optical absorption by fractal agglomerates of smoke aerosols, Atmos. Environ., 25A, 2563-2569, 1991.

Jacobson, M. Z.: Strong radiative heating due to the mixing state of black carbon in atmospheric aerosols, Nature, 409, 695-697, doi:10.1038/35055518, 2001.

Japar, S. M., Brachaczek, W. W., Gorse Jr., R. A., Norbeck, J. M., and Pierson, W. R.: The contribution of elemental carbon to the optical properties of rural atmospheric aerosols, Atmos. Environ., 20, 1281-1289, 1986.
Jayne, J. T., Leard, D. C., Zhang, X., Davidovits, P., Smith, K. A., Kolb, C. E., and Worsnop, D. R.: Development of an Aerosol Mass Spectrometer for size and composition analysis of submicron particles, Aerosol Sci. Technol., 33, 49-70, 2000.

Jennings, S. G. and Pinnick, R. G.: Relationship between visible extinction absorption and mass concentration of carbonaceous smokes, Atmos. Environ., 14, 1123-1129, 1980.

Jimenez, J. L., Jayne, J. T., Shi, Q., Kolb, C. E., Worsnop, D. R., Yourshaw, I., Seinfeld, J. H., Flagan, R. C., Zhang, X., Smith, K. A., Morris, J. W., and Davidovits, P.: Ambient aerosol sampling using the Aerodyne Aerosol Mass Spectrometer, J. Geophys. Res., 108, 8425, doi:10.1029/2001JD001213, 2003.

Kavouras, I. G., Mihalopoulos, N., and Stephanou, E. G.: Formation of atmospheric particles from organic acids produced by forests, Nature, 395, 683-686, 1998.

Kawamura, K. and Kaplan, I. R.: Motor exhaust emissions as a primary source for dicarboxylic acids in Los Angeles ambient air, Environ. Sci. Technol., 21, 105-110, 1987.

Kim, E. and Hopke, P. K.: Comparison between conditional probability function and nonparametric regression for fine particle source directions, Atmos. Environ., 38, 4667-4673, 2004.

Kim, D., Wang, C., Ekman, A. M. L., Barth, M. C., and Rasch, P. J.: Distribution and direct radiative forcing of carbonaceous and sulfate aerosols in an interactive sizeresolving aerosol-climate model, J. Geophys. Res., 113, D16309, doi:10.1029/2007JD009756, 2008.

Kirchstetter, T. W., Novakov, T., and Hobbs, P. V.: Evidence that the spectral dependence of light absorption by aerosols is affected by organic carbon, J. Geophys. Res., 109, DOI:10.1029/2004JD004999, 2004.

Kroll, J. H. and Seinfeld, J. H.: Chemistry of secondary organic aerosol: formation and evolution of low-volatility organics in the atmosphere, Atmos. Environ., 42, 3593-3624, 2008.

Laaksonen, A., Kulmala, M., O’ Dowd, C. D., Joutsensaari, J., Vaattovaara, P., Mikkonen, S., Lehtinen, K. E. J., Sogacheva, L., Dal Maso, M., Aalto, P., Petäjä, T., Sogachev, A., Yoon, Y. J., Lihavainen, H., Nilsson, D., Facchini, M. C., Cavalli, F., Fuzzi, S., Hoffmann, T., Arnold, F., Hanke, M., Sellegri, K., Umann, B., Junkermann, W., Coe, H., Allan, J. D., Alfarra, M. R., Worsnop, D. R., Riekkola, M.-L., Hyötyläinen, T., and Viisanen, Y.: The role of VOC oxidation products in continental new particle formation, Atmos. Chem. Phys., 8, 2657-2665, 2008,

http://www.atmos-chem-phys.net/8/2657/2008/.

Lack, D. A., Cappa, C. D., Covert, D. S., Baynard, T., Massoli, P., Sierau, B., Bates, T. S., Quinn, P. K., Lovejoy, E. R., and Ravishankara, A. R.: Bias in filter-based aerosol light absorption measurements due to organic aerosol loading: evidence from ambient measurements, Aerosol Sci. Technol., 42, 1033-1041, 2008.

Lewis, K. A., Arnott, W. P., Moosmller, H., Chakrabarty, R. K., Carrico, C. M., Kreidenweis, S. M., Day, D. E., Malm, W. C., Laskin, A., Jimenez, J. L., Ulbrich, I. M., Huffman, J. A., Onasch, T. B., Trimborn, A., Liu, L., and Mishchenko, M. I.: Reduction in biomass burning aerosol light absorption upon humidification: roles of inorganically-induced hygroscopicity, particle collapse, and photoacoustic heat and mass transfer, Atmos. Chem. Phys., 9, 8949-8966, 2009, http://www.atmos-chem-phys.net/9/8949/2009/.

Liousse, C., Cachier, H., and Jennings, S. G.: Optical and thermal measurements of black carbon aerosol content in different en- 
vironments: variation of the specific attenuation cross-section, Sigma, Atmos. Environ., 27A, 1203-1211, 1993.

Liu, L., Mishchenko, M. I., and Arnott, W. P.: A study of radiative properties of fractal soot aggregates using the superposition Tmatrix method, J. Quant. Spectrosc. Radiat. Transfer, 109, 26562663, 2008.

Liu, P. S. K., Deng, R., Smith, K. A., Williams, L. R., Jayne, J. T., Canagaratna, M. R., Moore, K., Onasch, T. B., Worsnop, D. R., and Deshler, T.: Transmission efficiency of an aerodynamic focusing lens system: comparison of model calculations and laboratory measurements for the Aerodyne Aerosol Mass Spectrometer, Aerosol Sci. Technol., 41, 721-733, 2007.

Mattew, B. M., Middlebrook, A. M., and Onasch, T. B.: Collection efficiencies in an Aerodyne Aerosol Mass Spectrometer as a function of particle phase for laboratory generated aerosols, Aerosol Sci. Technol., 42, 884-898, 2008.

Middlebrook, A. M., Murphy, D. M., and Thomson, D. S.: Observations of organic material in individual marine particles at Cape Grim during the First Aerosol Characterization Experiment (ACE 1), J. Geophys. Res., 103, 16475-16483, 1998.

Moosmüller, H., Chakrabarty, R. K., and Arnott, W. P.: Aerosol light absorption and its measurement: a review, J. Quant. Spectrosc. Radiat. Transfer, 110, 844-878, 2009.

Novakov, T. and Penner, J. E.: Large contribution of organic aerosols to cloud-condensation nuclei concentrations, Nature, 365, 823-826, 1993.

Novakov, T., Corrigan, C. E., Penner, J. E., Chuang, C. C., Rosario, O., and Mayol Bracero, O. L.: Organic aerosols in the Caribbean trade winds: A natural source? J. Geophys. Res., 102, 2130721313, 1997.

Pio, C., Alves, C., and Duarte, A.: Organic components of aerosols in a forested area of central Greece, Atmos. Environ., 35, 389401, 2001.

Robinson, A. L., Donahue, N. M., Shrivastava, M. K., Weitkamp, E. A., Sage, A. M., Grieshop, A. P., Lane, T. E., Pierce, J. R., and Pandis, S. N.: Rethinking organic aerosols: semivolatile emissions and photochemical aging, Science, 315, 1259-1262, 2007.

Rogge, W. F., Hildemann, L. M., Mazurek, M. A., Cass, G. R., and Simoneit, B. R. T.: Sources of fine organic aerosol, 4. particulate abrasion products from leaf surfaces of urban plants, Environ. Sci. Technol., 27, 2700-2711, 1993a.

Rogge, W. F., Mazurek, M. A., Hildemann, L. M., and Cass, G. R.: Quantification of urban organic aerosols at a molecular level: identification, abundance and seasonal variation, Atmos. Environ., 27, 1309-1330, 1993b.

Rupakheti, M., Leaitch, R., Lohmann, U., Hayden, K., Brickell, P., Lu, G., Li, S. M., Tomm-Sauntry, D., Bottenheim, J. W., Brook, J. R., Vet, R., Jayne, J. T., and Worsnop, D. R.: An intensive study of the size and composition of submicron atmospheric aerosols at a rural site in Ontario, Canada, Aerosol Sci. Technol., 39, 722-736, 2005.

Russell, L. M.: Aerosol organic-mass-to-organic-carbon ratio measurements, Environ. Sci. Technol., 37, 2982-2987, 2003.

Satheesh, S. K. and Moorthy, K. K.: Radiative effects of natural aerosols: a review, Atmos. Environ., 39, 2089-2110, 2005.

Schmid, O., Artaxo, P., Arnott, W. P., Chand, D., Gatti, L. V., Frank, G. P., Hoffer, A., Schnaiter, M., and Andreae, M. O.: Spectral light absorption by ambient aerosols influenced by biomass burning in the Amazon Basin. I: Comparison and field calibration of absorption measurement techniques, Atmos. Chem. Phys., 6, 3443-3462, 2006,

http://www.atmos-chem-phys.net/6/3443/2006/.

Sedlacek, A. and Lee, J.: Photothermal interferometric aerosol absorption spectrometry, Aerosol Sci. Technol., 41, 1089-1101, 2007.

Seinfeld, J. H. and Pandis, S. N.: Atmospheric chemistry and physics: from air pollution to climate change, John Wiley \& Sons, New York, 1998.

Sharma, S., Brook, J. R., Cachier, H., Chow, J., Gaudenzi, A., and Lu, G.: Light absorption and thermal measurements of black carbon in different regions of Canada, J. Geophys. Res., 107(D24), 4771, doi:10.1029/2002JD002496, 2002.

Slowik, J. G., Cross, E. S., Han, J. H., Davidovits, P., Onasch, T. B., Jayne, J. T., Williams, L. R., Canagaratna, M. R., Worsnop, D. R., Chakrabarty, R. K., Moosmüller, H., Arnott, W. P., Schwarz, J. P., Gao, R. S., Fahey, D. W., Kok, G. L., and Petzold, A.: An inter-comparison of instruments measuring black carbon content of soot particles, Aerosol Sci. Technol., 41, 295-314, 2007.

Slowik, J. G., Stroud, C., Bottenheim, J. W., Brickell, P. C., Chang, R. Y.-W., Liggio, J., Makar, P. A., Martin, R. V., Moran, M. D., Shantz, N. C., Sjostedt, S. J., van Donkelaar, A., Vlasenko, A., Wiebe, H. A., Xia, A. G., Zhang, J., Leaitch, W. R., and Abbatt, J. P. D.: Characterization of a large biogenic secondary organic aerosol event from eastern Canadian forests, Atmos. Chem. Phys. Discuss., 9, 18113-18158, 2009,

http://www.atmos-chem-phys-discuss.net/9/18113/2009/.

Snyder, D. C. and Schauer, J. J.: An inter-comparison of two black carbon aerosol instruments and a semi-continuous elemental carbon instrument in the urban environment, Aerosol Sci. Technol., 41, 463-474, 2007.

Strader, R., Lurmann, F., and Pandis, S. N.: Evaluation of secondary organic aerosol formation in winter, Atmos. Environ., 33, 48494863, 1999.

Subramanian, R., Roden, C. A., Boparai, P., and Bond, T. C.: Yellow beads and missing particles: trouble ahead for filter-based absorption measurements, Aerosol Sci. Technol., 41, 630-637, 2007.

Turpin, B. J., Cary, R. A., and Huntzicker, J. J.: An in situ, time-resolved analyzer for aerosol organic and elemental carbon, Aerosol Sci. Technol., 12, 161-171, 1990.

Turpin, B. J. and Huntzicker, J. J.: Secondary formation of organic aerosol in the Los Angeles basin: a descriptive analysis of organic and elemental carbon concentrations, Atmos. Environ., 25A, 207-215, 1991.

Turpin, B. J. and Huntzicker, J. J.: Identification of secondary organic aerosol episodes and quantitation of primary and secondary organic aerosol concentrations during SCAQS, Atmos. Environ., 29, 3527-3544, 1995.

Turpin, B. J., Saxena, P., and Andrews, E.: Measuring and simulating particulate organics in the atmosphere: problems and prospects, Atmos. Environ., 34, 2983-3013, 2000.

Turpin, B. J. and Lim, H. J.: Species contributions to PM2.5 mass concentrations: revisiting common assumption for estimating organic mass, Aerosol Sci. Technol., 35, 602-610, 2001.

Viana, M., Chi, X., Maenhaut, W., Cafmeyer, J., Querol, X., Alastuey, A., Mikuška, P., and Veea, Z.: Influence of sampling artefacts on measured PM, OC, and EC levels in carbonaceous aerosols in an urban area, Aerosol Sci. Technol., 40, 107-117, 
2006.

Viana, M., Querol, X., Alastuey, A., Ballester, F., Llop, S., Esplugues, A., Fernández-Patier, R., García dos Santos, S., and Herce, M. D.: Characterising exposure to PM aerosols for an epidemiological study, Atmos. Environ., 42, 1552-1568, 2008.

Virkkula, A., Ahlquist, N. C., Covert, D. S., Arnott, W. P., Sheridan, P. J., Quinn, P. K., and Coffman, D. J.: Modification, calibration and a field test of an instrument for measuring light absorption by particles, Aerosol Sci. Technol., 39, 68-83, 2005.

Volkamer, R., Jimenez, J. L., Martini, F. S., Dzepina, K., Zhang, Q., Salcedo, D., Molina, L. T., Worsnop, D. R., and Molina, M. J.: Secondary aerosol formation from anthropogenic air pollution: Rapid and higher than expected, Geophys. Res. Lett., 33, L17811, doi:10.1029/2006GL026899, 2006.

White, W. H. and Roberts, P. T.: On the nature and origins of visibility-reducing aerosols in the Los Angeles air basin, Atmos. Environ., 11, 803-812, 1977.

Zhang, Q., Alfarra, R., Worsnop, D. R., Allan, J. D., Coe, H., Canagaratna, M. R., and Jimenez, J. L.: Deconvolution and quantification of hydrocarbon-like and oxygenated organic aerosols based on Aerosol Mass Spectrometry, Environ. Sci. Technol., 39, 4938-4952, 2005a.
Zhang, Q., Worsnop, D. R., Canagaratna, M. R., and Jimenez, J. L.: Hydrocarbon-like and oxygenated organic aerosols in Pittsburgh: insights into sources and processes of organic aerosols, Atmos. Chem. Phys., 5, 3289-3311, 2005b, http://www.atmos-chem-phys.net/5/3289/2005/.

Zhang, Q., Jimenez, J. L., Canagaratna, M. R., Allan, J. D., Coe, H., Ulbrich, I., Alfarra, M. R., Takami, A., Middlebrook, A. M., Sun, Y. L., Dzepina, K., Dunlea, E., Docherty, K., DeCarlo, P. F., Salcedo, D., Onasch, T., Jayne, J. T., Miyoshi, T., Shimono, A., Hatakeyama, S., Takegawa, N., Kondo, Y., Schneider, J., Drewnick, F., Borrmann, S., Weimer, S., Demerjian, K., Williams, P., Bower, K., Bahreini, R., Cottrell, L., Griffin, R. J., Rautiainen, J., Sun, J. Y., Zhang, Y. M., and Worsnop, D. R.: Ubiquity and dominance of oxygenated species in organic aerosols in anthropogenically-influenced Northern Hemisphere midlatitudes, Geophys. Res. Lett., 34, L13801, doi:10.1029/2007GL029979, 2007.

Zobitz, J. M., Keener, J. P., Schnyer, H., and Bowling, D. R.: Sensitivity analysis and quantification of uncertainty for isotopic mixing relationships in carbon cycle research, Agric. For. Meteorol., 136, 56-75, 2006. 